\title{
Modelling the dispersion of particle numbers in five European cities
}

\author{
J. Kukkonen ${ }^{1}$, M. Karl ${ }^{2}$, M. P. Keuken ${ }^{3}$, H. A. C. Denier van der Gon ${ }^{3}$, B. R. Denby ${ }^{4,9}$, V. Singh ${ }^{5,10}$, J. Douros ${ }^{6}$, \\ A. Manders ${ }^{3}$, Z. Samaras ${ }^{6}$, N. Moussiopoulos ${ }^{6}$, S. Jonkers ${ }^{3}$, M. Aarnio ${ }^{1}$, A. Karppinen ${ }^{1}$, L. Kangas ${ }^{1}$, \\ S. Lützenkirchen ${ }^{7}$, T. Petäjä ${ }^{8}$, I. Vouitsis ${ }^{6}$, and R. S. Sokhi ${ }^{5}$ \\ ${ }^{1}$ Finnish Meteorological Institute, Helsinki, Finland \\ ${ }^{2}$ Helmholtz-Zentrum Geesthacht, Institute of Coastal Research, Geesthacht, Germany \\ ${ }^{3}$ TNO, Netherlands Organization for Applied Research, Utrecht, the Netherlands \\ ${ }^{4}$ Norwegian Institute for Air Research, Kjeller, Norway \\ ${ }^{5}$ Centre for Atmospheric and Instrumentation Research (CAIR), University of Hertfordshire, Hatfield, UK \\ ${ }^{6}$ Aristotle University of Thessaloniki, Thessaloniki, Greece \\ ${ }^{7}$ City of Oslo - Agency for Urban Environment, Oslo, Norway \\ ${ }^{8}$ University of Helsinki, Helsinki, Finland \\ ${ }^{9}$ Norwegian Meteorological Institute, Oslo, Norway \\ ${ }^{10}$ National Atmospheric Research Laboratory, Gadanki, Andhra Pradesh, India
}

Correspondence to: J. Kukkonen (jaakko.kukkonen@fmi.fi)

Received: 22 June 2015 - Published in Geosci. Model Dev. Discuss.: 28 July 2015

Revised: 23 November 2015 - Accepted: 5 January 2016 - Published: 4 February 2016

\begin{abstract}
We present an overview of the modelling of particle number concentrations (PNCs) in five major European cities, namely Helsinki, Oslo, London, Rotterdam, and Athens, in 2008. Novel emission inventories of particle numbers have been compiled both on urban and European scales. We used atmospheric dispersion modelling for PNCs in the five target cities and on a European scale, and evaluated the predicted results against available measured concentrations. In all the target cities, the concentrations of particle numbers (PNs) were mostly influenced by the emissions originating from local vehicular traffic. The influence of shipping and harbours was also significant for Helsinki, Oslo, Rotterdam, and Athens, but not for London. The influence of the aviation emissions in Athens was also notable. The regional background concentrations were clearly lower than the contributions originating from urban sources in Helsinki, Oslo, and Athens. The regional background was also lower than urban contributions in traffic environments in London, but higher or approximately equal to urban contributions in Rotterdam. It was numerically evaluated that the influence of coagulation and dry deposition on the predicted PNCs was substantial for the urban background in Oslo. The predicted and measured annual average PNCs in four cities agreed within approximately $\leq 26 \%$ (measured as fractional biases), except for
\end{abstract}

one traffic station in London. This study indicates that it is feasible to model PNCs in major cities within a reasonable accuracy, although major challenges remain in the evaluation of both the emissions and atmospheric transformation of PNCs.

\section{Introduction}

Airborne particulate matter (PM) affects human health and climate (e.g. Smith et al., 2009). While a large base of scientific information exists on particle mass, especially for $\mathrm{PM}_{10}$ and $\mathrm{PM}_{2.5}$, there are substantially less studies on particle numbers (PNs) and in particular on modelling dispersion of PNs in urban areas (e.g., Kumar et at., 2013). This may be attributed to (i) scarcity of reliable information on emissions, (ii) the greater complexity of physical and chemical atmospheric processes, and (iii) lack of monitoring data of PN. The majority of urban particles - in terms of number concentration - are ultrafine particles (UFP), i.e. particles with a diameter $\left(D_{\mathrm{p}}\right)<100 \mathrm{~nm}$, originating mainly from traffic-related emission (e.g. Morawska et al., 1998). The rapid transformation processes of $\mathrm{PN}$ after emissions in ambient air, such as condensation and evaporation, coagulation, 
dry deposition, and dilution pose challenges for dispersion modelling, especially on an urban scale (e.g. Pohjola et al., 2003; Ketzel et al., 2004; Kittelson et al., 2004; Kumar et al., 2011, von Bismarck-Osten et al., 2013). In addition, PN measurement techniques are also more complex and resource consuming, compared with the measurements of particulate mass fractions.

Although attention to the health effects of particulate matter has been focused on particle mass fractions, a number of studies are indicating that UFPs may have specific health effects. UFPs are poorly filtered in the human respiratory tract after inhalation, and such particles can penetrate the epithelial cells of the lungs and accumulate in lymph nodes ( Nel et al., 2006). Epidemiological and toxicological studies show a strong correlation between exposure to ultrafine particles and various health endpoints, such as cardiovascular hospital admission (short-term exposure), mortality (long-term exposure), and neurological effects (Oberdörster et al., 2004; Delfino et al., 2005; Atkinson et al., 2010; Franck et al., 2011; Daher et al., 2013; Loane et al., 2013).

There is a severe lack of representative sets of urban measurements of particle number concentrations (PNCs) that could be used in epidemiological studies, when compared to particle mass. Similarly, the scientific literature is scarce on predicting the dispersion of PNs in urban environments. It is therefore necessary to develop and evaluate dispersion modelling systems capable of reliably predicting PNCs.

Combustion is a direct source of UFPs, and secondary particle formation may occur via atmospheric reactions and condensation of semi-volatile components produced in photochemical reactions (Kulmala et al., 2013, 2014; Kumar et al., 2014). Combustion of carbon-based fuels for power generation, heating, and transport are important sources for PN emissions (Shi et al., 2001; Obaidullah et al., 2012; Kittelson et al., 2006; Maricq, 2007; Buzea et al., 2007; Kumar et al., 2013; Keuken et al., 2015a, b). In most European cities, road traffic emissions of PNs are expected to be the most important source for exposure of the population, due to the nearground emissions and the vicinity of road traffic to populated areas.

The importance of aerosol processes has been analysed via aerosol process timescales by Zhang and Wexler (2004) and Ketzel and Berkowicz (2004). Pohjola et al. (2003) simulated the transformation and dilution of particulate matter on a distance scale of less than $100 \mathrm{~m}$ from a road in an urban area. As expected, dilution was found to be the most important process affecting the PNCs; however, condensation of an insoluble organic vapour was also found to be important, if its concentration exceeds a certain threshold value. Ketzel and Berkowicz (2004) evaluated that the influence of dry deposition would be irrelevant on an urban timescale. Kerminen et al. (2007) evaluated that coagulation, condensation, and evaporation could be important in conditions, where dilution with cleaner background air is restricted.
Small-scale combustion may also be a prominent source of PNCs in winter (Glasius et al., 2008). Elevated levels of PNs have also been found in specific areas, such as, near harbors, refineries, and in particular near airports (González and Rodríguez, 2013; Westerdahl et al., 2008; Zhu et al., 2011; Keuken et al., 2012; Hsu et al., 2014). Whereas most of the state-of-the-art chemical-transport models include treatments for aerosol size distributions and microphysics (Kukkonen et al., 2012), such treatments are substantially less commonly included in urban-scale models. There are currently very few models that are especially designed to predict particle number concentrations by taking into account particle dynamics. Kumar et al. (2013) presented a review on the importance of aerosol transformation processes at various urban scales and environments.

A first European size-resolved anthropogenic PN emission inventory was compiled in the framework of the EUfunded European Integrated project on Aerosol Cloud Climate and Air Quality interactions (EUCAARI) project (Denier van der Gon and Hulskotte, 2010). Consolidated emission factor data bases (e.g., COPERT, PARTICULATES, and TRANSPHORM) have recently become available to establish PN emission inventories in Europe; these have been reviewed by Kumar et al. (2014). According to the inventory by Paasonen et al. (2012), for the 28 EU countries in 2010, road transport contributed over $60 \%$ of the total PN emissions, non-road transport (including partly also shipping) 19\%, and domestic combustion $13 \%$.

The first stage between the point of emission (vehicle tailpipe) and the kerbside is characterized by strong turbulence generated by the moving vehicles. According to Zhang and Wexler (2004), the initial stages of dilution within a few first seconds would be accompanied with nucleation. Onroad measurements by Rönkkö et al. (2007) demonstrated that the nucleation mode was already present after $0.7 \mathrm{~s}$ residence time in the atmosphere. However, the modelling of nucleation will require detailed information about the environmental conditions very near the tailpipe (e.g., temperature gradient, and chemical composition and concentrations of volatile nucleating vapours). Nucleation mode particles grow rapidly by condensation of high-molecular weight lowvolatile hydrocarbons from the unburned lubrication oil and sulfur compounds (Kittelson et al., 2006).

In the second stage between the street and a few hundred metres away from the street, atmospheric turbulence, induced by wind and atmospheric instability, is the main cause for dilution of particle concentrations. In this stage, condensation/evaporation and dilution become the major mechanisms in altering the particle size distribution, while coagulation and deposition play minor roles (Zhang et al., 2004). In the third stage, between street canyon/street neighbourhood and the urban background, the number size distribution is altered by multiple processes, such as dilution with cleaner air, entrainment of polluted air, condensation of vapours, oxida- 
tive ageing, and coagulation of particles (e.g., Wehner et al., 2002).

Asmi et al. (2011) examined aerosol number size distribution data from 24 European field monitoring sites in 2008 and 2009. The data were collected from the stations at the EUSAAR (European Supersites for Atmospheric Aerosol Research) and GUAN networks (German Ultrafine Aerosol Network), and represented mainly regional background or remote locations. They categorized the aerosol to several types: central European aerosol, Nordic aerosol, mountain sites, and southern and western European regions, and analysed the seasonal characteristics and patterns of the various size modes.

Hussein et al. (2007) and Pohjola et al. (2007) conducted a field measurement campaign near a major road in an urban area in Helsinki in February 2003. Measured PNC data at various distances from the road was compared with dispersion and aerosol process model predictions. A similar measurement campaign was conducted downwind of a motorway in Rotterdam (Keuken et al., 2012). Size-resolved PNC measurements were compared with dispersion modelling and an aerosol process model (Karl et al., 2011). Both these studies concluded that dilution was shown to be the most important process.

Gidhagen et al. (2005) implemented a three-dimensional dispersion model in Stockholm and presented the spatial distribution of number concentrations over the whole city. Typical number concentrations in the urban background of Stockholm were $10000 \mathrm{~cm}^{-3}$, and approximately 7 times higher close to a major highway and 7 times higher within a densely trafficked street canyon. Coagulation was found to contribute to losses of PNCs of only a few percent, compared to particles, which are assumed not to coagulate, while including dry deposition resulted in PNC losses of up to $25 \%$ in certain locations. Removal of PNs due to coagulation and deposition was more significant during peak episodes.

This study is part of the EU-funded research project TRANSPHORM (Transport-related Air Pollution and Health impacts - Integrated Methodologies for Assessing Particulate Matter). This project was one of the very few international projects, where dispersion models have been developed and applied to predict spatially and temporally resolved concentrations of PN for exposure and health applications (www.transphorm.eu). The cities Helsinki, Oslo, Rotterdam, London, and Athens were involved to test the methodologies developed within the TRANSPHORM project at an urban scale. These cities were selected in order to include at least one major urban agglomeration from the following regions: (i) the Nordic countries (Helsinki and Oslo), (ii) central and north-western Europe (Rotterdam and London), and (iii) the Mediterranean region (Athens).

Health studies for PN are scarce. According to the expert elicitation study by Hoek et al. (2010), there will be a $0.3 \%$ increase in all-cause mortality per $10^{3}$ particles per $\mathrm{cm}^{3}$. Source-exposure functions based on original epidemi-

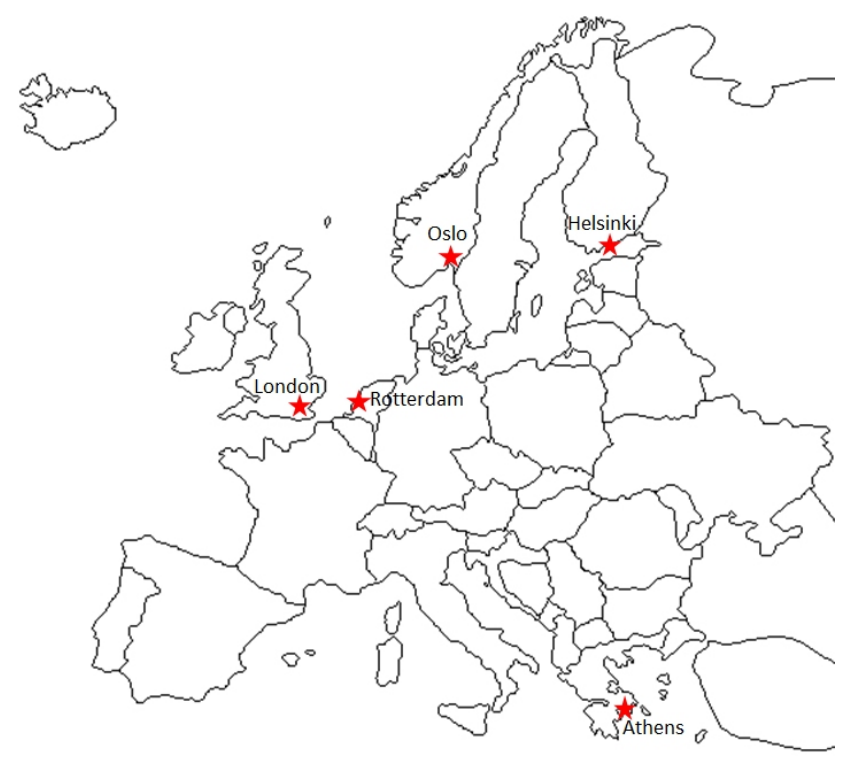

Figure 1. The target cities of this study.

ological studies for PN have been presented by Stolzel et al. (2007) and Atkinson et al. (2010). Von Klot et al. (2005) underlined similar effects for hospital re-admissions of a susceptible population, in cases, for which the aerosol number increased $10^{3}$ particles per $\mathrm{cm}^{3}$ or aerosol mass by $10 \mu \mathrm{g} \mathrm{m}^{-3}$. However, in view of the potential health effects for exposure to PNCs, there is a need to combine epidemiological data and PNCs with a high spatial resolution.

The aim of this article is to present an overview of the modelling of PNCs on an urban scale in five major European cities, presented in Fig. 1: Helsinki, Oslo, Rotterdam, London, and Athens. The target cities represent megacities, such as London (population of approximately 8.3 million) and Athens (we address here Greater Athens, 3.5 million), and other major cities, such as the Helsinki metropolitan area, Oslo, and Rotterdam (populations of 1.0, 0.6 and 0.6 million, respectively). For simplicity, we refer to Helsinki metropoli$\tan$ area simply as "Helsinki" in the following. The primary year used in the computations is 2008. The modelling of PNCs for these cities has been presented in the present article for the first time. The previous literature also does not contain any compilations of PNC modelling for several cities.

We address emission inventories and emission modelling of PN, dispersion modelling of PNCs, numerical results on the annual average spatial distributions in the target cities, and evaluation of the predicted results against measured PNCs. The main scientific goals were (i) to evaluate the capability of models to predict PNCs in several European cities, (ii) to examine the predicted spatial characteristics of PN in the selected cities, (iii) to evaluate the contributions of various source categories on the concentrations, and (iv) to highlight areas of improvements in modelling PN for healthbased studies. 


\section{Modelling methods}

In this section the computational methods are presented, which were used for the evaluation of PNCs in the five target cities. We address both the methods for the evaluation of emissions, and the atmospheric dispersion modelling systems. For practical reasons, it was not possible to completely harmonize the computations, by using only one modelling system for all the cities. All of the urban emission and dispersion modelling systems were therefore locally or nationally developed ones; these were different for each city. However, the regional background concentrations for all the urban-scale modelling systems were computed with the same model, the Long-term Ozone Simulation - European Operational Smog (LOTOS-EUROS) chemicaltransport model (Schaap et al., 2008). We have therefore also briefly discussed a new European-scale emission inventory used as input for the above-mentioned regional-scale chemical-transport model.

\subsection{Overview of the PNC computation in the target cities}

For readability, selected summary information has been presented in Table 1 on the urban-scale computations. The more detailed information will be presented in the following sections.

The TRANSPHORM project emission database was used on an urban scale in three of the target cities. Two urban modelling systems applied a meteorological pre-processing model, two others other meteorological models, and one modelling system applied directly measured data. All the models included the emissions from vehicular traffic. The shipping emissions were explicitly included in the computations of Oslo, Rotterdam, and Athens, and the importance of primary shipping emissions was separately evaluated for Helsinki (Soares et al., 2014). For London, the local-scale shipping emissions were not taken into account, as its importance was found to be negligible. Most models included also the emissions from major and/or small-scale stationary sources, or a quantitative estimate of their importance within the target cities (for Helsinki, Oslo, London, and Athens) and other source categories (for Oslo, Rotterdam, London, and Athens).

The urban-scale emission and dispersion modelling systems were specific for each target city. All of the urban dispersion modelling systems used for Helsinki, Oslo, London, and Rotterdam are multi-source Gaussian dispersion and transformation systems. These can also allow for dispersion in street canyons; however, these street canyon dispersion models were not used in this study (except for using the semi-empirical street canyon model for Rotterdam). The modelling system for Athens is based on the combined use of a meteorological model and a chemical-transport model. All these modelling systems have previously been extensively evaluated against experimental data.

Regional background concentrations of PN were derived from the LOTOS-EUROS model computations for three target cities (Oslo, London, and Rotterdam), based on the predicted values at grid squares that surrounded these cities. However, we used measured values for the urban or regional background for Helsinki and Athens, respectively. The predicted LOTOS-EUROS regional background values were scaled, using the ratios of measured and predicted annual average concentrations, for Oslo and London.

The aerosol transformation processes of nucleation and condensation of $\mathrm{H}_{2} \mathrm{SO}_{4}$, and coagulation of particles were taken into account in the LOTOS-EUROS computations. The model also includes treatments for the dry and wet deposition. Measured PNC data were available in four of the cities, in three of these for a complete year, although only at one or two measurement stations for each city.

\subsection{Emission inventories}

We describe in this section both a new European-scale emission inventory and the urban emission inventories in the five target cities.

\subsubsection{European-scale emission inventory}

A new emission inventory was compiled for the EU-wide anthropogenic transport activities, supplemented by the anthropogenic non-transport activities. In addition to this anthropogenic emission inventory, we included various natural emission sources in the LOTOS-EUROS computations. These included sea spray aerosol emissions, and the dust emissions from road suspension, agriculture, and bare soils. These were modelled as described by Schaap et al. (2008).

The baseline emission data in the anthropogenic emission inventory contains the following substances: $\mathrm{NO}_{x}, \mathrm{SO}_{2}$, non-methane volatile organic compounds (NMVOC), $\mathrm{CH}_{4}$, $\mathrm{NH}_{3}, \mathrm{CO}, \mathrm{PM}_{10}, \mathrm{PM}_{2.5}, \mathrm{EC}$ (elemental carbon), $\mathrm{B}[\mathrm{a}] \mathrm{P}$ (benzo[a]pyrene), and PN (Denier van der Gon et al., 2014). The anthropogenic PN inventory includes particles in the size range of $10-300 \mathrm{~nm}$.

The emission data can be calculated for the individual countries; the official UN ISO3 Country Codes were used. We have used three groups of countries. The EU15+ group is defined to include EU15 as well as Norway and Switzerland. The EU12+ group contains the new member states, Malta and European non-EU countries; the latter refers to the other European countries in the United Nations Economic Commission for the Europe domain. The EU27+ group consists of EU15+ and EU12+. Emissions from international shipping have been estimated for the various European sea regions.

The first European particle number emission inventory was made in the EU FP6 project EUCAARI (Denier van der 
Table 1. Overview information on the computational methods and the evaluation of predictions in the five target cities for 2008.

\begin{tabular}{|c|c|c|c|c|c|}
\hline & Helsinki & Oslo & Rotterdam & London & Athens \\
\hline $\begin{array}{l}\text { Traffic flows and } \\
\text { urban-scale emissions }\end{array}$ & $\begin{array}{l}\text { Traffic planning model, } \\
\text { vehicular emission fac- } \\
\text { tors (Gidhagen et al., } \\
\text { 2005), shipping emis- } \\
\text { sion model STEAM2 }\end{array}$ & $\begin{array}{l}\text { Local traffic data, } \\
\text { TRANSPHORM emis- } \\
\text { sion database (Vouitsis } \\
\text { et al., 2014) with tem- } \\
\text { perature correction, } \\
\text { STEAM2 }\end{array}$ & $\begin{array}{l}\text { Local traffic data, } \\
\text { COPERT IV (Gkat- } \\
\text { zoflias et al., 2012) and } \\
\text { TRANSPHORM emis- } \\
\text { sion database (Vouitsis } \\
\text { et al., 2014) }\end{array}$ & $\begin{array}{l}\text { Local traffic data, emis- } \\
\text { sion factors (Jones and } \\
\text { Harrison, 2006) }\end{array}$ & $\begin{array}{l}\text { Local traffic data, } \\
\text { TRANSPHORM emis- } \\
\text { sion database and other } \\
\text { data (Petzold et al., } \\
\text { 2010; Lee et al., 2010) }\end{array}$ \\
\hline $\begin{array}{l}\text { Meteorological data } \\
\text { and its pre-processing }\end{array}$ & $\begin{array}{l}\text { Meteorological pre- } \\
\text { processor model } \\
\text { MPP-FMI, based on } \\
\text { measured sounding } \\
\text { data and other data } \\
\text { from two stations }\end{array}$ & $\begin{array}{l}\text { Diagnostic wind field } \\
\text { model, based on mea- } \\
\text { sured data at two sites }\end{array}$ & $\begin{array}{l}\text { Measured data from lo- } \\
\text { cal airport }\end{array}$ & $\begin{array}{l}\text { Meteorological pre- } \\
\text { processor } \\
\text { GAMMA-met, based } \\
\text { on measured data at } \\
\text { one station }\end{array}$ & $\begin{array}{l}\text { Prognostic model } \\
\text { MEMO, based on } \\
\text { measured data at one } \\
\text { location }\end{array}$ \\
\hline $\begin{array}{l}\text { Urban source } \\
\text { categories included }\end{array}$ & $\begin{array}{l}\text { Vehicular traffic, im- } \\
\text { portance of shipping } \\
\text { and major stationary } \\
\text { sources separately eval- } \\
\text { uated }\end{array}$ & $\begin{array}{l}\text { Vehicular traffic, ship- } \\
\text { ping, small-scale com- } \\
\text { bustion, industry, other } \\
\text { sources }\end{array}$ & $\begin{array}{l}\text { Vehicular traffic, ship- } \\
\text { ping, airports and re- } \\
\text { fineries included in the } \\
\text { regional background }\end{array}$ & $\begin{array}{l}\text { Vehicular traffic, all the } \\
\text { sources influencing ur- } \\
\text { ban background }\end{array}$ & $\begin{array}{l}\text { Vehicular traffic, ship- } \\
\text { ping, aviation, station- } \\
\text { ary sources }\end{array}$ \\
\hline $\begin{array}{l}\text { Regional or urban } \\
\text { background concentra- } \\
\text { tions and their evaluation }\end{array}$ & $\begin{array}{l}\text { Urban background val- } \\
\text { ues measured at an ur- } \\
\text { ban background station }\end{array}$ & $\begin{array}{l}\text { LOTOS-EUROS, re- } \\
\text { gional background } \\
\text { values at the grid } \\
\text { squares that surround } \\
\text { the city, scaled using } \\
\text { measured regional } \\
\text { background values }\end{array}$ & $\begin{array}{l}\text { LOTOS-EUROS, re- } \\
\text { gional background } \\
\text { values at a grid square } \\
\text { that surrounds the city }\end{array}$ & $\begin{array}{l}\text { LOTOS-EUROS, re- } \\
\text { gional background } \\
\text { values at grid squares } \\
\text { that surround the city }\end{array}$ & $\begin{array}{l}\text { The measured regional } \\
\text { background PNC val- } \\
\text { ues by Kalivitis et al. } \\
(2008) \text {. The values of } \\
\text { other relevant com- } \\
\text { pounds were extracted } \\
\text { from LOTOS-EUROS } \\
\text { at grid squares sur- } \\
\text { rounding the city }\end{array}$ \\
\hline $\begin{array}{l}\text { Urban modelling } \\
\text { system }\end{array}$ & $\begin{array}{l}\text { CAR-FMI, PN treated } \\
\text { as tracer }\end{array}$ & $\begin{array}{l}\text { EPISODE, Aerosol } \\
\text { process parameterisa- } \\
\text { tion included }\end{array}$ & $\begin{array}{l}\text { URBIS:street-canyon } \\
\text { and line-source models; } \\
\text { PN treated as tracer }\end{array}$ & $\begin{array}{l}\text { OSCAR, PN treated as } \\
\text { tracer }\end{array}$ & $\begin{array}{l}\text { MARS-aero, } \\
\text { treated as tracer }\end{array}$ \\
\hline $\begin{array}{l}\text { Evaluation of predictions } \\
\text { against measured concen- } \\
\text { trations }\end{array}$ & $\begin{array}{l}\text { At one measurement } \\
\text { station for one year }\end{array}$ & $\begin{array}{l}\text { At two measurement } \\
\text { stations, for three } \\
\text { months }\end{array}$ & $\begin{array}{l}\text { At two measurement } \\
\text { stations for one year }\end{array}$ & $\begin{array}{l}\text { At two measurement } \\
\text { stations, for one year }\end{array}$ & $\begin{array}{l}\text { Measurements were not } \\
\text { available for } 2008\end{array}$ \\
\hline
\end{tabular}

Gon et al., 2010a; Kulmala et al., 2011). This inventory was used as a starting point for the present study. For the different transport modes (road, rail, air, and maritime navigation), a new bottom-up PN emission estimate was made, including also technologies and activities in the future years, 2020 and 2030.

The above-mentioned PN emission inventory includes only anthropogenic sources; the emissions from mainly natural sources, such as wild land fires, windblown dust, and sea salt, are not included. The inventory also does not include vegetation-related emissions (e.g., Guenther et al., 1995), or the formation of PNCs from biogenic VOCs (volatile organic compounds) (e.g., Paasonen et al., 2012).

The above-mentioned emission inventory describes internally mixed PN emissions originating from several source categories in 12 size bins, covering the particle dry diameter range from 10 to $250 \mathrm{~nm}$. The LOTOS-EUROS model in combination with the M7 module uses the PN emission as input; that is converted into the Aitken and accumulation modes used in the M7 module. The M7 module additionally requires the associated masses of black and organic carbon, sulfate and mineral dust, and a division to soluble and insolu- ble material. Using the sulfate content of the internally mixed particles as a proxy, the PN concentrations were attributed to the soluble and insoluble modes.

\subsubsection{Urban-scale emission inventories in the target cities}

\section{Emission inventory for Helsinki}

The emission inventory included exhaust emissions from vehicular traffic for the network of roads and streets in the Helsinki metropolitan area (HMA). The traffic volumes and average travel speeds of each traffic link were computed using the EMME/2 transportation planning system (INRO, 1994). Traffic volume data in 2008 was used as input for the estimation of annual average road traffic emissions in the HMA. The final emission inventory consisted of average hourly emissions for each line source over the year, separately for weekdays, Saturdays, and Sundays.

The emission factors for vehicular traffic determined by Gidhagen et al. (2005) in Stockholm have been used. They reported fleet aggregate emission factors of particle number, based on measurements of the contribution of a ve- 
hicular fleet in different urban micro-environments. These values were estimated to optimally correspond to the climatic and traffic conditions in Helsinki. These values are $2.70 \times 10^{15}$ and $1.8 \times 10^{14}$ particles $\mathrm{km}^{-1}$ per vehicle for heavy- and light-duty vehicles, respectively. This approach does not specify separate emission factor values for diesel and gasoline vehicles; instead such composite emission factors represent the combined emissions originating from both diesel and gasoline vehicles. These values were determined for driving speeds less than $70 \mathrm{~km} \mathrm{~h}^{-1}$; however, we have applied these values for all urban roads included in the computations. Clearly, measurements are also available for the PN emission factors, based on laboratory measurements (e.g., Giechaskiel et al., 2012). However, the values determined in laboratory studies are specific for the measured individual vehicles, driving cycles, and dilution rates.

In addition to the computations for 2008, we computed the PNCs at the roadside traffic station at Ring road 1, Malmi (called simply as "Ring road 1" in the following), in 2012, for model evaluation purposes. For the hourly computations in 2012, the 2008 traffic volume data were scaled using the ratio of the total vehicular mileage $\left(\mathrm{km} \mathrm{a}^{-1}\right)$ in the HMA in 2008 and 2012. These mileage values were obtained from the national traffic emissions data archive LIPASTO (http: //lipasto.vtt.fi/en/index.htm).

The importance of the shipping emissions was evaluated based on Soares et al. (2014). They showed using the STEAM2 shipping emission modelling (Jalkanen et al., 2012; Johansson et al., 2013) that the contribution of primary shipping emissions of to the concentrations of $\mathrm{PM}_{2.5}$ are only $3 \%$ on the average in the Helsinki metropolitan area. However, this contribution can be higher than $20 \%$ in the vicinity of the harbours (within a distance of approximately $1 \mathrm{~km}$ ).

Emissions from stationary sources were not included. However, major stationary sources in the area (these are mostly power plants) have previously been shown to have a negligible effect on the $\mathrm{PM}_{2.5}$ concentrations near the ground level in Helsinki (Kauhaniemi et al., 2008); the same was assumed to be valid also for PNCs. Emissions from small-scale combustion were not taken into account, as their spatial distribution was not known with sufficient accuracy. The contribution of small-scale combustion to the total $\mathrm{PM}_{2.5}$ emissions in the Helsinki metropolitan area has been estimated to be $23 \%$ in 2009 (Malkki et al., 2010). The emissions of $\mathrm{PM}_{2.5}$ originated from aviation in the Helsinki metropolitan area were about $17 \%$ of the total road traffic $\mathrm{PM}_{2.5}$ emissions in the area in 2008 .

\section{Emission inventory for Oslo}

Emission factors for traffic exhaust (measured at an ambient temperature of $+33^{\circ} \mathrm{C}$ ) were extracted from the emission database of the TRANSPHORM project (Vouitsis et al., 2014) Emission factors for PN in Oslo and in other studies (Klose et al., 2009; Olivares et al., 2007) have been found to have a significant dependence on ambient air temperature. A dependence of $-3 \% \mathrm{~K}^{-1}$ has been applied to the Oslo traffic emissions, leading to significantly higher emission factors in the cold winter period (approximately double) than those provided in the emissions database.

Shipping emissions were based on the STEAM2 emission model (Jalkanen et al., 2012; Johansson et al., 2013). Emissions for $\mathrm{PN}$ were based on the $\mathrm{CO}_{2}$ emissions, converted first back to fuel consumption, and then PN emissions were calculated using an emission factor of $1 \times 10^{16}$ particles $(\mathrm{kg} \text { fuel })^{-1}$, recommended by Petzold et al. (2010). Shipping emissions were evaluated in a domain of $29 \mathrm{~km} \times 18 \mathrm{~km}$ and thus only included shipping in the Oslo fjord area.

Domestic heating emissions of PN, due mostly to wood burning, were calculated based on a previously compiled $\mathrm{PM}_{2.5}$ inventory. A conversion factor of $4 \times 10^{14}$ particles $\left(\mathrm{g} \mathrm{PM}_{2.5}\right)^{-1}$ emitted was used to convert $\mathrm{PM}_{2.5}$ emissions to $\mathrm{PN}$ emissions, based on the data presented in Hedberg et al. (2002). Other emissions concerning combustion sources, i.e. agricultural, industrial, and mobile sources use the existing $\mathrm{PM}_{2.5}$ emissions inventory and convert to $\mathrm{PN}$ using a ratio similar to diesel truck emissions; a conversion factor of $3 \times 10^{15}$ particles $\left(\mathrm{g} \mathrm{PM}_{2.5}\right)^{-1}$ was applied.

\section{Emission inventory for Rotterdam}

Road traffic data and road characteristics were obtained from a national database (www.nsl-monitoring.nl). Road traffic data contains information about the number of vehicles, speed, congestion, and fleet composition in-between traffic links for every major road and motorway in Rotterdam. The road characteristics refer to, e.g., the width and height of buildings along the road.

The following emission factors from COPERT IV (Gkatzoflias et al., 2012) and the TRANSPHORM database have been applied: (i) for motorway traffic, $10^{15}$ particles $\mathrm{km}^{-1} \mathrm{veh}^{-1}$ for heavy- and light-duty vehicles, and $0.3 \times 10^{15}$ particles $\mathrm{km}^{-1} \mathrm{veh}^{-1}$ for passenger cars; and (ii) for urban road traffic, $0.5 \times 10^{15}$ particles $\mathrm{km}^{-1} \mathrm{veh}^{-1}$ for heavy- and light-duty vehicles and buses, and $0.3 \times 10^{15}$ particles $\mathrm{km}^{-1} \mathrm{veh}^{-1}$ for passenger cars.

As mentioned above, two composite emission factors were used for passenger cars, one for motorway traffic, and the other one for traffic in urban roads. This was necessary, as the available traffic flow data were also in composite form, including a value for each street for each of the following vehicle categories: passenger cars, lorries, and busses. The assumption of composite emission factors implies that the fractions of passenger cars equipped with diesel, petrol, and vehicle technologies are not spatially variable within the city. However, these composite emission factors take into account, e.g., the differences between the emission factors of cars using gasoline and diesel fuels. 
Airports and refineries can be potentially important sources for PN emissions (Keuken et al., 2015a, b). However, the Airport Rotterdam is a relatively small airport; for example, the annual average number of passengers is smaller than $10 \%$ of that of the main airport in the Netherlands, the Schiphol Airport in the vicinity of Amsterdam. Major refineries are located at a distance of $10 \mathrm{~km}$ west of the modelling domain. Both the emissions from the Airport Rotterdam and refineries have therefore been included in the regional background.

\section{Emission inventory for London}

The road traffic data for London have been obtained from London Atmospheric Emission Inventory (LAEI; GLA, 2010). Each road link was characterised by the amount of vehicles per day per vehicle category and mean speed. The traffic activity data were disaggregated by vehicle categories such as motorcycles, cars including taxis, buses, lightgoods vehicles (LGV) and heavy-goods vehicles (HGV). The HGVs are further subdivided into articulated HGVs and rigid HGVs categories. The fleet compositions have been further subdivided as per fuel type, weight, engine size, and emission standards.

The emission model in the current version of the OSCAR system commonly uses the emission functions and factors based on COPERT IV (Gkatzoflias et al., 2012) and the Department for Transport (DfT) emission data base. However, due to the unavailability of emissions in that database for PNs, emission factors from Jones and Harrison (2006) have been used in this study.

According to the LAEI (GLA, 2010), the most important source categories of $\mathrm{PM}_{10}$ in London in 2015 were road transport, agriculture-nature, and industrial processes. The $\mathrm{PM}_{10}$ emission from shipping was only 2 ton year ${ }^{-1}$, which is a negligible fraction $(0.08 \%)$ of total emissions. We therefore neglected the influence of shipping in the case of London. The contribution of mass-based particulate matter emissions originating from small-scale house heating is also negligible, compared with that of the other main source categories in London. We therefore did not include house heating as a separate source category in the urban-scale computations in London.

\section{Emission inventory for Athens}

For Athens, PN emissions included vehicular traffic, shipping, and aviation. Emission factors for traffic exhausts were taken from the TRANSPHORM emission database (Vouitsis et al., 2014). Emissions from shipping and the major ports, and airport emissions were calculated on the basis of the operational action plan for air pollution management in Athens. This plan was developed for 2004, using activity and fuel consumption data (Samaras et al., 2012). The emission factor used for shipping was
$10^{16}$ particles (kg fuel) $)^{-1}$ according to Petzold et al. (2010), and for aviation $6 \times 10^{14}$ particles $(\mathrm{kg} \text { fuel })^{-1}$, assuming a fuel sulfur content of $1000 \mathrm{ppm}$ (Lee et al., 2010).

\subsection{Dispersion and transformation modelling}

First, we address the dispersion modelling on a continental scale, which provided the regional background concentrations for urban dispersion modelling. Second, we discuss the urban-scale dispersion modelling systems used in the five target cities.

\subsubsection{Chemical-transport modelling on a European scale}

The chemistry-transport model LOTOS-EUROS (Schaap et al., 2008) was used in this study to evaluate the regional background PNCs. Compared with other widely used chemical-transport models in Europe, reviewed by Kukkonen et al. (2012), the model is of intermediate complexity. The relevant processes have been parameterized in such a way that the computational demands are modest. The LOTOS-EUROS model has been included in several international model inter-comparison studies that have addressed the dispersion and transformation of ozone and particulate matter (e.g., Stern et al., 2008; Solazzo et al., 2012a, b). The model performance has in these model inter-comparisons been comparable with other European chemical-transport models.

The M7 aerosol microphysics module (Vignati et al., 2004) was coupled to the LOTOS-EUROS model. This module accounts for nucleation and condensation of $\mathrm{H}_{2} \mathrm{SO}_{4}$, and coagulation of particles. The default nucleation scheme was replaced by the activation type parameterization of Kulmala et al. (2006), which is better suited for the boundary layer. In the model treatment, the processes of nucleation and condensation are interdependent; they are linked by the availability of $\mathrm{H}_{2} \mathrm{SO}_{4}$. In the $\mathrm{M} 7$ module, the amount of $\mathrm{H}_{2} \mathrm{SO}_{4}$ that is available for nucleation is limited by the amount of $\mathrm{H}_{2} \mathrm{SO}_{4}$ that is condensed onto existing particles, within each numerical time step.

Formation of $\mathrm{H}_{2} \mathrm{SO}_{4}$ was based on the default gas-phase chemistry of LOTOS-EUROS, using emission inventories provided by the MACC (Monitoring Atmospheric Composition and Climate) project (TNO-MACC emission inventory) and the TRANSPHORM emission inventories. The PN emissions were converted to values that are compatible with the M7 module, using assumptions on the chemical composition of particulate matter (cf. Sect. 2.2.1).

Although the size range of the anthropogenic emissions was assumed to be from 10 to $300 \mathrm{~nm}$, the dispersion computations were performed for the size range of $10-1000 \mathrm{~nm}$. There are several reasons for the relatively wider size range of the dispersion computations. First, due to condensation and coagulation, particles may grow to larger sizes than 
$300 \mathrm{~nm}$. Second, small particles interact with larger particles (even larger than $300 \mathrm{~nm}$ ); the latter can originate from natural sources such as sea salt. The structure of the M7 model also includes the Aitken and accumulation size modes, with no strict separation at $300 \mathrm{~nm}$.

Two sets of simulations for Europe were made, for the target years of the TRANSPHORM project, viz. 2008 and 2005. (i) The first set was based on the meteorology of 2008, and was used for model evaluation. This set had a $0.5 \times 0.25$ longitude-latitude grid, for a European domain from $15^{\circ} \mathrm{W}$ to $35^{\circ} \mathrm{E}$ and from 35 to $70^{\circ} \mathrm{N}$. The concentrations for particle numbers were assumed to be negligible at the boundaries of the domain. (ii) The second set of simulations was performed for the meteorology and the emissions of 2005. Additional simulations were performed for each target city, on a finer $0.125 \times 0.0625$ longitude-latitude grid, for each city in a domain that covered an area of $3^{\circ} \times 1.5^{\circ}$, using the European-scale simulation for boundary conditions.

There are several processes that contribute to uncertainties in the model results. Nucleation mode particles contribute substantially to the total particle numbers. However, several parameterizations for nucleation processes are available, and it is not in all cases clear, which are the optimal ones. The uncertainties associated with the modelling of particle nucleation have mainly an impact on the number concentration of particles smaller than $100 \mathrm{~nm}$ (e.g., Fountoukis et al., 2012).

Some atmospheric species are not represented in the M7 module. For example, secondary aerosol formation from biogenic emissions (such as isoprene and terpene) is not taken into account. Riipinen et al. (2011) investigated the role of condensable vapours on the growth of freshly nucleated particles until the cloud condensation nuclei size, and proposed a semi-empirical modelling approach. Secondary organic vapours can condense on existing particles, and thus contribute to their growth. This process increases the probability of such particles to reach the sizes that are cloud condensation nuclei (CCN) active, before getting scavenged by the background particle population. Secondary organic aerosol from biogenic origin therefore may substantially contribute to the PNCs.

The emissions of condensable gases from combustion processes are also not taken into account in the modelling; these could potentially contribute, e.g., in areas with substantial residential wood burning. In regions with intensive $\mathrm{NH}_{3}$ emissions (e.g., from agriculture and animal husbandry), the impact of secondary inorganic aerosol may be significant on number and size distribution of particulate matter; this is not accounted for in the M7 module (Vignati et al., 2004).

The omission of biogenic secondary aerosol causes inaccuracies to the PM size distribution. The inaccuracies are the largest in the case of the smallest particles. The modelled sum of the Aitken and accumulation mode particle number concentrations are therefore considered the most appropriate quantity to represent regional background PNCs in this study (compared with using the number concentration of the nucleation mode particles).

\subsubsection{Urban-scale dispersion modelling}

For each modelling system, we address (i) the urban dispersion modelling system and its implementation, (ii) the evaluation of meteorological variables (used as input for the urban modelling), and (iii) the assessment of regional background concentrations.

\section{Dispersion modelling for Helsinki}

The urban-scale dispersion of vehicular emissions was evaluated with the CAR-FMI (Contaminants in the Air from a Road - Finnish Meteorological Institute; Kukkonen et al., 2001; Härkönen et al., 1996) model. The model computes an hourly time-series of the pollutant dispersion from the line source. The dispersion equation for the line source model is based on a semi-analytical solution of the Gaussian diffusion equation for a finite line source. The dispersion parameters are modelled as a function of the Monin-Obukhov length, the friction velocity and the mixing height. Traffic-originating turbulence is modelled with a semi-empirical treatment.

The receptor grid intervals range from $20 \mathrm{~m}$ in the vicinity of major roads to $500 \mathrm{~m}$ on the outskirts of the area. The concentration values were computed at 18692 receptor points.

Input data needed by the dispersion model was evaluated using a meteorological pre-processing (MPP-FMI) model that has been adapted for an urban environment (Karppinen et al., 2000). The MPP-FMI model is based on the energy budget method. The model utilises meteorological synoptic and sounding observations, and its output consists of estimates of the hourly time series of the relevant atmospheric turbulence parameters and the boundary layer height. The computation is based on a combination of the data from the stations at Helsinki-Vantaa airport and Helsinki-Kumpula ( $3 \mathrm{~h}$ synoptic weather observations), and Jokioinen (soundings).

The urban background concentrations of PN both for 2008 in 2012 were estimated to be equal to the measured hourly values at an urban background measurement site located at Kumpula in Helsinki. This station is part of the network of stations called Station for Measuring Ecosystem - Atmosphere Relations (SMEAR-III) (Järvi et al., 2009). This data contained PNCs in the particle size range from 3 to $950 \mathrm{~nm}$. The measurements and data analysis were conducted according to Wiedensohler et al. (2012). Therefore, for the computations in Helsinki we did not use the regional background concentration values predicted by the LOTOSEUROS model. 


\section{Dispersion and particle transformation modelling for Oslo}

Calculations of concentrations were carried out using the EPISODE dispersion model, which is part of the integrated air quality management tool AirQUIS (Slørdal et al., 2008). The EPISODE model consists of a gridded Eulerian model coupled with a Gaussian line source model for modelling the local contribution at receptor points near roads. The Eulerian grid model uses a $1 \mathrm{~km} \times 1 \mathrm{~km}$ grid covering Oslo. There are 13 vertical layers in the model, up to the height of $4000 \mathrm{~m}$, with the lowest layer being $10 \mathrm{~m}$ thick. Emissions from traffic sources are placed in the lowest layer, whilst emissions from domestic heating, industry, and shipping are placed in the layers between 10 and $35 \mathrm{~m}$.

Receptor points within $500 \mathrm{~m}$ of a road include line source calculations, using the Gaussian line source model in EPISODE; otherwise, only the Eulerian model contributes. The model coupling leads to a double counting of the emissions near roads, which has been estimated to contribute a maximum increase of 5-20\% to the model concentrations at receptor points near roads. The receptor points are placed at monitoring sites, and at aggregated home addresses, at the centre of population mass within a $100 \mathrm{~m} \times 100 \mathrm{~m}$ grid.

The air pollution originating in vehicular traffic tunnels has been modelled assuming that there has been no deposition of particles within the tunnels. The tunnel exits are therefore treated simply as exit points of polluted air.

Meteorology is generated in the model using the diagnostic wind field model MCWIND. The MCWIND model uses meteorological measurements and interpolates these in space, adjusting for topography and atmospheric stability. Measurements from two sites are used (Valle Hovin and Blindern); both sites are centrally located in Oslo. Data required by the dispersion modelling are atmospheric stability, wind speed, and wind direction.

Hourly regional background concentrations were derived using predictions from the LOTOS-EUROS model at a number of grid squares surrounding Oslo. The hourly median concentration from these grid squares was extracted for this purpose. These values were further adjusted, based on a comparison of the predicted and observed annual mean PNC measurements at Birkenes (located about $300 \mathrm{~km}$ south of Oslo). This procedure resulted in a rescaling of all LOTOSEUROS predictions by a factor of 0.75 .

In Oslo, a parametrization was applied to account for deposition and coagulation processes. This was only applied in the gridded model calculations, but not in the sub-grid Gaussian modelling. This parametrization is based on calculations using the MAFOR (model for aerosol transformation and dynamics) aerosol process model for road traffic emissions (Keuken et al., 2012). First, MAFOR calculations were carried out using the complete aerosol process model description and then, for simplicity, the emissions and calculations were binned into three particle size classes. Based on these computations, deposition and coagulation rates in these three size classes were derived.

The change of the PNC in each size bin caused by coagulation was parameterized in the following simplified form:

$\left.\frac{\mathrm{dPNC}_{i}}{\mathrm{~d} t}\right|_{\text {coag }}=-\mathrm{PNC}_{i}^{2} \overline{K_{\mathrm{c}, i}}$,

where the subscripts $i$ and "coag" refer to the particle size class and coagulation, respectively, and $K_{\mathrm{c}, i}$ is the coagulation rate derived using the MAFOR model. Dry deposition is described as

$\left.\frac{\mathrm{dPNC}_{i}}{\mathrm{~d} t}\right|_{\text {depo }}=-\mathrm{PNC}_{i} \frac{\overline{v_{\mathrm{d}, i}}}{H_{\text {grid }}}$,

where $v_{\mathrm{d}, i}$ is the dry deposition rate for the $i$ th size class and $H_{\text {grid }}$ is the depth of the lowest model grid layer.

\section{Dispersion modelling for Rotterdam}

In Rotterdam, the contribution of traffic to air quality near inner-urban roads was modelled with the urban dispersion modelling system URBIS (model for local environmental assessments) (Eerens et al., 1993; Vardoulakis et al., 2003). This modelling system contains various submodules, such as a model for line sources, called the Pluim Snelweg model, and a model for evaluating the concentrations in street canyons, called the CAR model.

Up to a distance of $500 \mathrm{~m}$, contribution from motorways was modelled with the line source dispersion module, Pluim Snelweg (Wesseling et al., 2003; Beelen et al. 2010; Keuken et al., 2012). This line source model is a Gaussian plume model. The modelling also takes into account the vehicleinduced turbulence, the roughness of the terrain, the noise screens near the motorway and the atmospheric stability. The treatments of concentration time series is based on the concept of stratified meteorology. A time series of wind speeds and directions, observed at the airport of Rotterdam, are first clustered as a frequency distribution. The contributions downwind of the motorway, based on averaged emission rates, are then weighted using these frequencies; this procedure results in an estimate for the annual average concentration.

The street canyon dispersion model CAR is based on the results of wind tunnel experiments at different road types, including street canyons. The ratio of the height of the buildings and the width of the street is used to classify the type of street canyon. A source-receptor relationship has been specified as a function of the distance to the street axis for five different road types. All streets in Rotterdam have been categorized in accordance to the model classification. The model simulates only annually averaged concentrations. The model therefore requires as input values the annually averaged emission rates, and the reciprocal annual average wind speed. The annual average concentration is assumed to be inversely proportional to the wind speed. The wind speed was 
retrieved from measurements by the National Meteorological Institute at the airport of Rotterdam.

The contribution of shipping to the PNCs was estimated based on a predicted spatial distribution of the emissions of $\mathrm{NO}_{x}$ from shipping in the Netherlands in 2007 (Snijder et al., 2012). The $\mathrm{NO}_{x}$ emission map was evaluated based on computations using as input the automatic identification signals (AIS) of ships. These computations applied for operational shipping parameters, e.g., navigational status and payload, which were based on the AIS signals. The total $\mathrm{NO}_{x}$ emissions were scaled to correspond to the year 2008, using the total amounts of emissions from shipping in the Netherlands in 2007 and 2008 (Denier van der Gon and Hulskotte, 2010). The spatial distribution of the emissions of $\mathrm{NO}_{x}$ was subsequently converted to the emissions of PNs, based on the observations by Petzold et al. (2010). The conversion was done using the average ratio of the $\mathrm{NO}_{x}$ and $\mathrm{PN}$ emissions in the observations of Petzold et al. (2010).

The atmospheric dispersion of shipping emissions was evaluated using the Dutch Standard Gaussian dispersion model. This model applies the same treatment of atmospheric dispersion as the Pluim Snelweg model. For simplicity, we assumed a constant stack height of $30 \mathrm{~m}$ and the heat content of exhausts of 1.0 MW, for all the ships within the region.

The urban background of PNCs was estimated based on the LOTOS-EUROS model, at a grid square that surrounds Rotterdam. The urban-scale modelling has a spatial resolution of $10 \mathrm{~m} \times 10 \mathrm{~m}$, up to a distance of $30 \mathrm{~m}$ from the streets, or alternatively at the housing façade along street canyons, and up to a distance of $500 \mathrm{~m}$ near motorways.

\section{Dispersion modelling for London}

The OSCAR air quality assessment system (Singh et al., 2013; Sokhi et al. 2008) has been used to estimate trafficrelated PNCs across London. The models within the OSCAR system consist of an emission model, meteorological pre-processing model, and a line source Gaussian dispersion model. The roadside dispersion model within OSCAR system is the CAR-FMI model. The hourly concentrations were predicted at the receptor points placed at varying distances of 10,40 , and $90 \mathrm{~m}$ near both sides of the roads, and $100 \mathrm{~m}$ apart in the outskirts.

A range of hourly meteorological parameters are needed, including wind speed, solar radiation, friction velocity, and Monin-Obukhov length. These are provided by the dedicated OSCAR meteorological pre-processor GAMMA met, described by Bualert (2002). The meteorological model employs meteorological data, such as solar radiation, roughness length, and heat flux, to estimate atmospheric stability parameters, including the Monin-Obukhov lengths and mixing heights. Data from the meteorological station at Heathrow was used as input for the model. The effects of land use characteristics on parameters such as surface roughness, Bowen ratio, albedo, and anthropogenic heat flux are taken into ac- count. The meteorological pre-processor needs six input parameters: time, wind speed, wind direction, ambient temperature, cloud cover, and global radiation.

The regional background levels were evaluated based on the LOTOS-EUROS simulations. We used the predicted LOTOS-EUROS concentration values surrounding the city. The LOTOS-EUROS hourly values were scaled by multiplying them with the ratio of annual average measured and predicted concentrations. The measured values used for the scaling were taken from the regional background station of Harwell.

\section{Dispersion modelling for Athens}

The modelling system consists of two models: (i) the meteorological model MEMO (Moussiopoulos et al., 1993), and (ii) the chemical-transport model MARS-aero (Moussiopoulos et al., 1995, 2012). The MEMO model is a threedimensional Eulerian non-hydrostatic prognostic model. The MARS-aero model can be used to simulate the transport and transformation of gaseous pollutants and atmospheric aerosols in the lower troposphere. The system allows for a finer grid simulation to be nested inside a coarser grid.

Meteorological data were generated using the MEMO model. Initialisation and boundary conditions data for the application of the MEMO model were based on upper air soundings for selected meteorological variables (wind speed and direction, temperature); these were performed at the Athens International Airport. Annual mean concentrations were estimated on the basis of computations for eight representative days, combined with a weighting scheme. These days were selected and assigned certain weights based on a classification of synoptic meteorological conditions in the Greater Athens area for 2008 (Helmis et al., 2003; Moussiopoulos et al., 2004).

The classification was done with the application of principal component analysis on a set of six meteorological variables (namely wind speed and direction, surface pressure, mixing layer height, cloud cover, and specific humidity), and subsequently using a subtractive clustering algorithm. Using this procedure, the different synoptic weather conditions that prevailed during each day of the year were distributed into distinct groups, which correspond to certain characteristic meteorological features (Sfetsos et al., 2005; Shahgedanova et al., 1998).

The day that appeared closer to the mean of each group of synoptic meteorological conditions was considered to be a typical day representing the specific group and was simulated with MARS-aero. The weight assigned to each of the representative days was proportional to the size of the corresponding group. The application of the methodology was based on meteorological fields predicted by the WRF meteorological model (version 3.2.1, Skamarock et al., 2005), which was applied for 2008 with a horizontal grid resolution of $50 \mathrm{~km}$ and a temporal resolution or $3 \mathrm{~h}$. The MEMO and 
MARS-aero models were applied in a computational domain of $50 \mathrm{~km} \times 50 \mathrm{~km}$, on a spatial resolution of $500 \mathrm{~m}$.

Both the regional background PNCs and the concentrations of other relevant species are needed as boundary conditions for the MARS-aero calculations. A spatially uniform annually average regional PNC background of 1800 particles $\mathrm{cm}^{-3}$ was used for the boundary conditions, based on Kalivitis et al. (2008). The regional background values of all other relevant species were extracted from the LOTOS-EUROS computations, at the grid squares surrounding the city.

\subsection{The measurements of PN concentrations in target cities}

The measurements at the station of Kumpula in Helsinki in 2008 and 2012 were performed using a Differential Mobility Particle Sizer; the particle concentrations were determined at the size range from 3 to $950 \mathrm{~nm}$. Particle number concentrations at the station of Ring road 1, Malmi, were measured using a Grimm butanol condensation particle counter (CPC), with detection limit from $5 \mathrm{~nm}$ to larger than $3 \mu \mathrm{m}$.

In Oslo, the Grimm 565 Environmental Wide Range Aerosol Spectrometer system was used for the measurements. This system combines a Grimm 190 aerosol spectrometer OPC (optical particle counter), and a scanning mobility particle sizer with a condensation particle counter $(\mathrm{SMPS}+\mathrm{C})$. The entire system in principle covers the range from $5 \mathrm{~nm}$ to $30 \mu \mathrm{m}$. For this study only the particle sizes below $350 \mathrm{~nm}$, measured using the SMPS $+\mathrm{C}$ instrument, have been used. For the modelling and comparison with measurements we have used a lower cut-off of $8.5 \mathrm{~nm}$.

The measured values of hourly PNC concentrations for London were available from Defra's Particle Numbers and Concentrations Network, which uses CPC. This CPC measures the number of particles in the size range from $7 \mathrm{~nm}$ up to several $\mu \mathrm{m}$ in size.

Total PNC in Rotterdam was measured using a CPC with a lower $50 \%$ cut-off at $3 \mathrm{~nm}$ and an upper limit of $3 \mu \mathrm{m}$. Sizeresolved PNC was measured with a SMPS. The SMPS consists of a differential mobility analyser (DMA) covering a size range from 10 to $480 \mathrm{~nm}$ and a CPC with a lower $50 \%$ cut-off at $4 \mathrm{~nm}$ and an upper size limit of $1.5 \mu \mathrm{m}$.

\section{Results and discussion}

\subsection{Emissions}

\subsubsection{Emissions in Europe and their associated uncertainties}

Total anthropogenic PN emissions in UNECE (United Nations Economic Commission for Europe) Europe were estimated using a bottom-up methodology (Denier van der Gon et al., 2014). These are presented in Fig. 2a-b, classified ac-
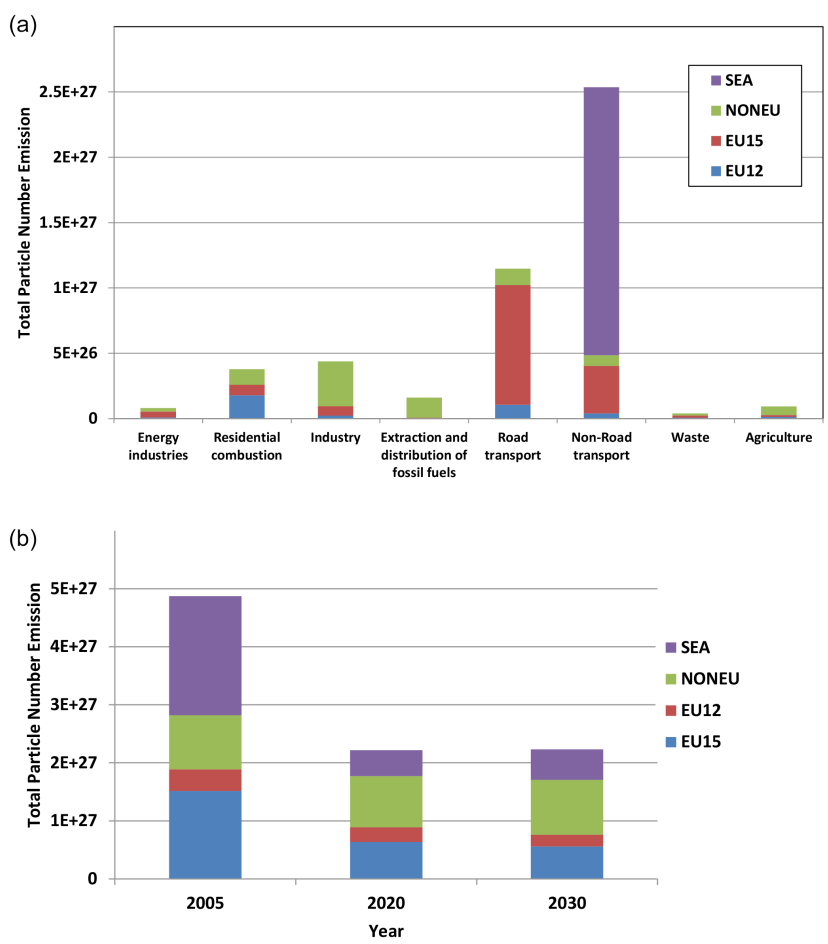

Figure 2. Total anthropogenic particle number emissions in the United Nations Economic Commission for Europe, (a) classified by the source sector for 2005 , and (b) classified by the country group for 2005, 2020, and 2030. "Sea" refers to international shipping.

cording to both source sector and country group. The transport sectors (i.e., road and non-road transport) contributed approximately $60 \%$ to the total land-based PN emissions in UNECE-Europe in 2005 (Fig. 2a). The other most important sectors include industry (defined here excluding energy industries), residential combustion, fugitive emissions, and energy industries.

The PN emissions are projected to decrease in 2020 and 2030 to less than a half of their value in 2005 (Fig. 2b). International shipping was a dominating source in 2005 , but its contribution is expected to substantially decline from 2005 to 2020 and 2030, mainly due to the introduction of low sulfur fuels. The contribution of shipping is more dominant in the current inventory, compared with the first European PN emission inventory made in the EU-funded project EUCAARI (Denier van der Gon et al., 2010a; Kulmala et al., 2011). Another remarkable change compared with the previous inventory is that in the new inventory, aviation is a substantially stronger source of UFPs than previously assumed. Most of these shipping and aviation particulate emissions are not solid, but semi-volatile particles, and may therefore have escaped attention in previous emission factor measurements.

The PN emission inventory includes in principle all particulate sizes. The PN emissions in two size fractions have been presented in Fig. 3a. The UFP is defined as particles smaller in diameter than $100 \mathrm{~nm}$. As expected, the difference 

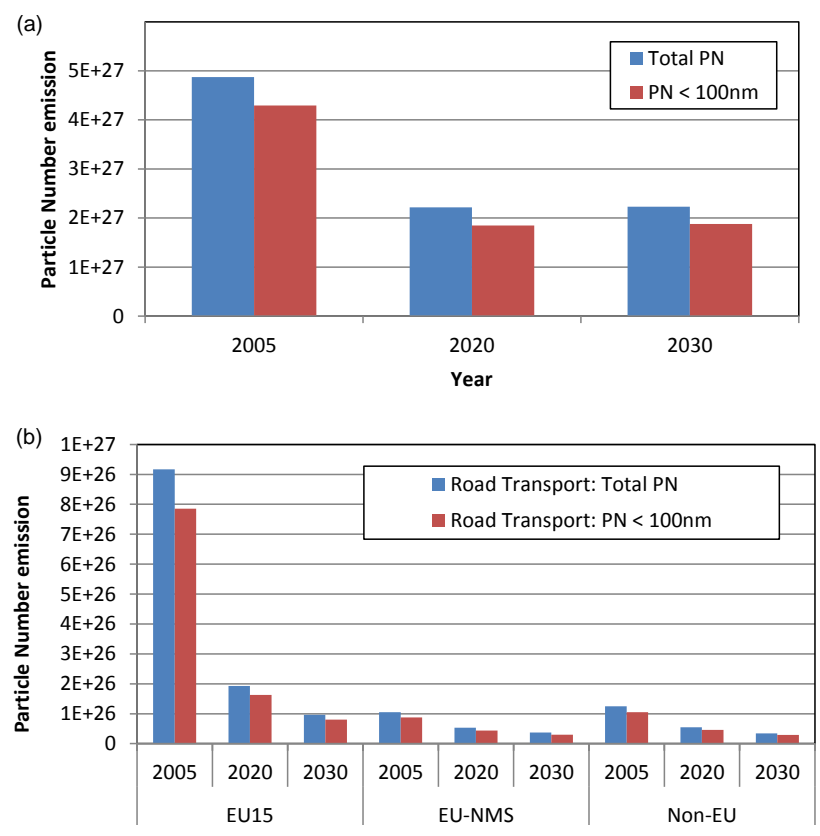

Figure 3. (a) Total anthropogenic particle number emissions and total particle number emissions in the particle size range of 10$100 \mathrm{~nm}$ for UNECE Europe for 2005, 2020, and 2030 and (b) the same emissions exclusively for road transport, segmented by country group. NMS refers to the new member states, i.e., EU12+.

between the total PN emissions and the UFP emissions is relatively small, as the PN emissions are dominated by the smaller size fractions.

The corresponding emissions solely for the road transport sector have been presented in Fig. 3b. The PN emissions of road transport are projected to significantly decrease in time (Fig. 3b). The PN emissions due to fuel combustion in road transport and shipping are expected to significantly decrease as a consequence of motor and fuel modifications, such as low-sulfur fuels and particulate matter filters (e.g., Ristovski et al., 2006; Morawska et al., 2008; Fiebig et al., 2014). The EU 15 emissions are estimated to decline strongly in future years, due to implementation of new emission standards in road transport, and the phase-out of the older vehicles that have less stringent emission limits.

To facilitate the modelling of PN on a regional scale, the PN emissions were spatially distributed using available proxy data (Denier van der Gon et al., 2010b). Examples of such proxy data are maps of population density, road networks, shipping tracks, land use, and port capacities. The spatial distribution of the PN emissions has been presented in Fig. 4.

The estimates for PN emissions are associated with a relatively high uncertainty, compared with the emissions of the commonly regulated pollutants. This uncertainty varies substantially in terms of the different source categories. Vehicleoriginated PNCs can change on a short timescale after the

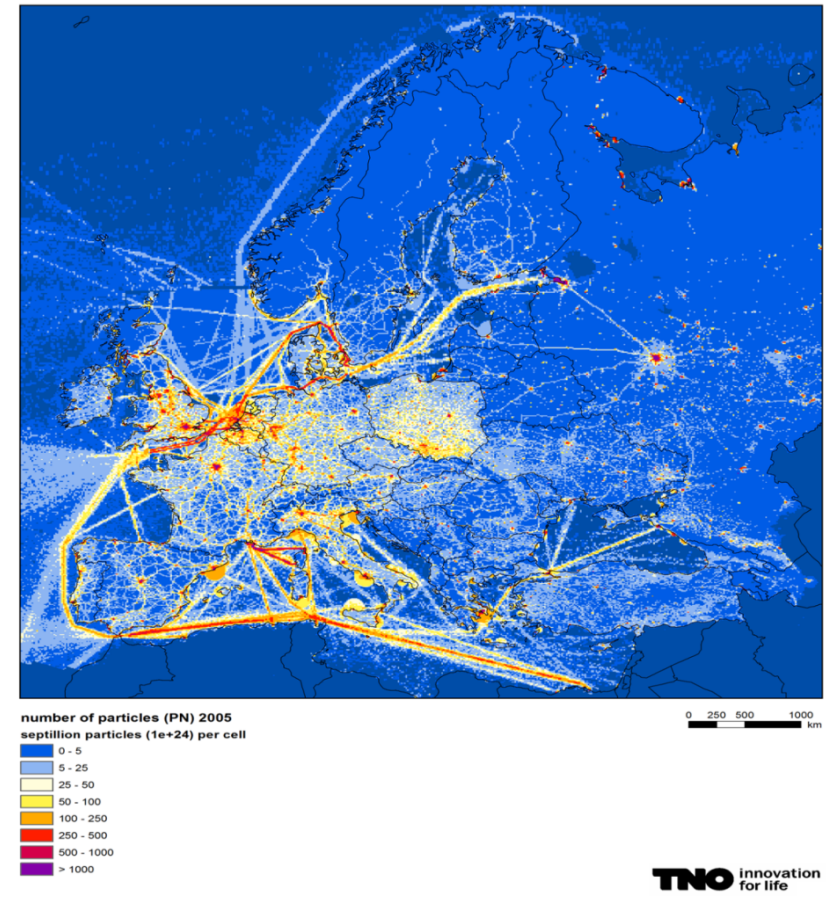

Figure 4. Spatial distribution of anthropogenic PN emissions in Europe in 2005, on a longitude-latitude grid, on a resolution of $1 / 8^{\circ} \times 1 / 16^{\circ}$. The unit of the legend is $10^{24}$ particles per computational cell per annum.

emissions exit the tailpipe, due to both rapid dilution and microphysical processes. The latter depend on ambient temperature and other environmental conditions, as well as on secondary particle formation. Due to such transformations, the $\mathrm{PN}$ concentration flux is not conserved. For some source categories, no PN emission factors were available. In such cases, the PN emission was calculated based on PM measurements and estimated particle size distributions.

For the road transport emission factors reported here, an uncertainty analysis for the particle mass-based emission has been carried out. This analysis shows an uncertainty between 10 and $20 \%$, depending on the quality of the country's statistics (Kioutsioukis et al., 2010). Particulate number emission factors were not included in the uncertainty evaluation of the above-mentioned study. However, it is possible also to indirectly estimate the uncertainties of the PN emissions, based on the correlations between PN emission factors derived in this study with the COPERT PM emission factors (Vouitsis et al., 2014).

Solid particles can be measured more accurately than semi-volatile ones; the emission standards for road transport are therefore currently based on the solid fraction of PN. The $\mathrm{PN}$ emissions are influenced by numerous factors, such as, e.g., vehicle category, PN measuring equipment, and environmental conditions. The overall uncertainty of vehicular PN emissions can therefore be evaluated to have high un- 
certainties: (i) $81-144 \%$ when after-treatment device effects are not included and (ii) $144-169 \%$ when these effects are included (UNECE, 2010).

Road transport is the most intensively studied source category for PN emissions. It can therefore be expected that the uncertainties for other source categories are at least of the same magnitude. For example, the total PN emission factor is dependent on the set-ups of the measurements. In particular, the measurement can (i) include only solid PN, or solid and volatile PN, and (ii) the lower particle size cut-off used in the measurements can vary, as this is dependent on the instrumental method. Sometimes a lower cut-off of $3 \mathrm{~nm}$ is used, but frequently also only PNs for sizes larger than 20 or $30 \mathrm{~nm}$ are reported. This definition of lower size cut-off can have substantial effects on the estimates of the total PN emissions. For a more detailed discussion of the various techniques used to measure PN, we refer to McMurry (2000) and Morawska et al. (2008).

Another important uncertainty is caused by the sulfur content in shipping fuels. It is known what the regulatory limit values for the fuel sulfur content are, and in some cases also what the average fuel sulfur content is; however, it is not commonly known what the actual values are. Therefore, for all transport modes the uncertainty is expected to be at least equal to the previously listed uncertainty estimate for road transport; this is in the range of 100-170\%.

On a regional to city-scale, Kalafut-Pettibone et al. (2011) determined average size-resolved and total number- and volume-based emission factors for combustion. They estimated that the uncertainty of the PN emission factor is approximately plus or minus $50 \%$. This uncertainty value is based on longer-term temporal averages.

\subsubsection{Emissions in the target cities}

All of the emission inventories in the target cities included vehicular traffic. However, the details of the treatments for other source categories varied substantially from city to city. The urban inventories for Helsinki, Oslo, Rotterdam and Athens included also the primary particulate matter emissions from shipping. In the case of London, the importance of shipping emissions was found to be negligible, compared with that of other urban emissions. The stationary sources were included at varying levels of detail for Helsinki, Oslo, London, and Athens. In the case of Rotterdam, the airports, refineries, and other major sources were included in the regional background. For Helsinki, the influence of shipping and major stationary sources was estimated indirectly, but the actual PN emission values for these source categories were not included in the urban emission inventory. The influence of small-scale combustion was explicitly evaluated for Oslo, and its importance was evaluated for Helsinki.

The sulfur content of vehicular motor fuel is an important factor for selecting the emission factors of PNs. There has been a decreasing trend in the fuel sulfur (S) contents in Europe. During the later part of 2000's, the S content of motor fuels was decreasing rapidly in many European countries, commonly from $<50 \mathrm{ppm}$ to $<10 \mathrm{ppm} \mathrm{S}$. One should therefore use the vehicular emission factors (EFs) that were determined for the same $\mathrm{S}$ content as for the target year of modelling (in this study 2008). For all the target cities, we used the best available locally applicable EFs.

For Helsinki, calculations were based on EFs by Gidhagen et al. (2005) for Stockholm. The measurements that were the basis for these EFs were made in Stockholm for heavy-duty vehicles (HDV) in 1999 and for light-duty vehicles (LDV) in 2003. Sweden introduced its Environmental Class 1 (EC1) diesel fuel in 1991, with maximum sulfur content of $10 \mathrm{ppm}$ (weight). The EC1 grade reached nearly complete market coverage in Sweden already in the 1990s, due to a strongly supportive tax policy. The EFs used for Helsinki therefore refer to fuel with lower than $10 \mathrm{ppm}$ sulfur content. As also Finland used the lower S content vehicular fuel in 2008, the EFs used in the manuscript are appropriate in this respect. Also in Oslo and Rotterdam both the modelled and actual $\mathrm{S}$ contents of the vehicular fuel were lower than $10 \mathrm{ppm}$ in 2008.

For London, the emission factors from Jones and Harrison (2006) were used, which refer to the higher $(<50 \mathrm{ppm})$ fuel $\mathrm{S}$, while the target year for modelling (2008) was after the transition to lower $\mathrm{S}$ fuel. For Athens, the situation was the opposite: EFs correspond to the lower fuel S content, whereas a higher $\mathrm{S}$ content fuel was actually used. The applied EFs are therefore expected to somewhat overestimate the measured concentrations in London, and underestimate those in Athens.

The most detailed emission inventory was compiled for Oslo. The proportions of total emissions in Oslo in 2008 have been presented in Fig. 5. The sector denoted "heating" includes all heating, of which domestic heating is the largest part, $95 \%$. Traffic exhaust emissions were responsible for about three-fourths of the total emissions; the contributions from shipping, heating, and other mobile sources are also notable.

\subsection{Modelled concentrations}

\subsubsection{Concentrations in Europe}

The LOTOS-EUROS model, including the M7 module, was used together with the above-mentioned new PN emission inventory, to evaluate the PNCs in Europe.

\section{Evaluation of predicted concentrations with measured values on a European scale}

The predicted PNCs were compared with the EUCAARI measurements (Asmi et al., 2011), with a focus on eight selected stations: Cabauw, Melpitz, Vavihill, Harwell, SMEAR, Ispra, Kosetice, and Kpuszta. Cabauw is a rural 


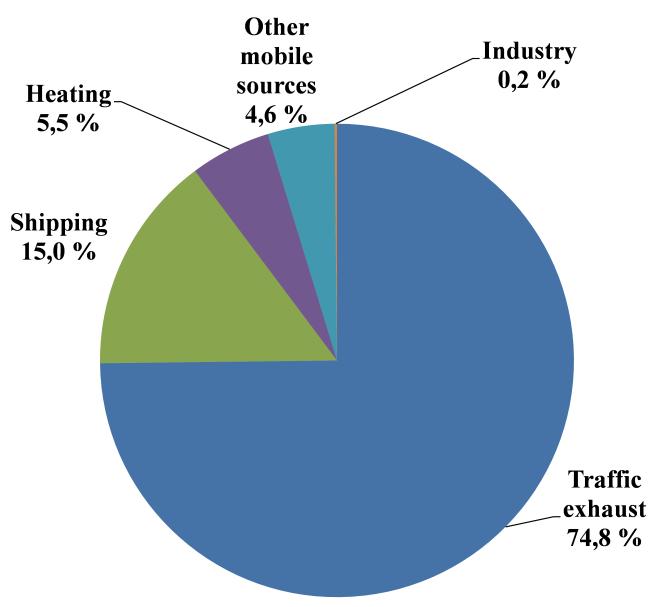

Figure 5. The contributions of various source categories on the total emissions of particulate number in Oslo in 2008. The total amount of emissions was $1.1 \times 10^{24}$ particles year $^{-1}$.

site in an agricultural area in the Netherlands, with influence from the nearby city of Rotterdam; this is the type of region for which the model is well suitable. Melpitz is a rural site in Germany, the concentrations of which are dominated by long-range transport and biogenic emissions. The site of Vavihill in Sweden is close to the sea; this site is representative for fairly clean background conditions, with occasional influence from shipping and nearby cities. The station of Harwell (UK) is a regional background site that can occasionally be influenced by the urban plumes originating in London. The SMEAR II site (in Hyytiälä, southern Finland) is a highlatitude regional station, exposed alternatively to both clean and fairly polluted air masses. The site of Ispra (Italy) is in the vicinity of the Alps; it experiences the influences of the polluted air from the Po Valley. The site of Kosetice (Czech Republic) is located in the agricultural countryside. Kpuszta represents the central European regional background, relatively far from local sources.

Modelled PNCs in the Aitken and accumulation mode were compared with the observed PNCs in size bins 30$50 \mathrm{~nm},>50 \mathrm{~nm}$, and $>100 \mathrm{~nm}$ (the latter two bins are partly overlapping). Measured and modelled monthly average PNCs for the eight sites have been presented in Fig. 6a-d. The nucleation mode was excluded. The values correspond to the size fraction $30-250 \mathrm{~nm}$ for the observations, and the sum of Aitken and accumulation mode for the LOTOS-EUROS computations (defined as the interval $10-1000 \mathrm{~nm}$ ).

At Vavihill, the modelled and observed monthly average concentrations match well for the whole year. At Cabauw, the observed concentrations from January to April were not measured at the ground level, but instead at a height of $60 \mathrm{~m}$; these values are therefore not comparable with the predictions. Since May, the overall measured and predicted levels of the PNCs at Cabauw were fairly well in agreement. The modelled monthly average concentrations at Melpitz were clearly lower than the corresponding measured values. These relatively high measured values have probably been caused by the substantial contribution of particles formed from biogenic emissions, which were not accounted for in the present model version. In winter, when the biogenic emissions are smaller, the model and observations match relatively better at Melpitz. The predicted monthly concentrations at Harwell agree well with the measurements; the model is well suited for this type of environment. For the site of SMEAR, the model under-predicts; contributions from biogenic emissions in summer are not taken into account in the model. For the site of Ispra, the concentrations in winter were the highest observed amongst the stations considered here, and the model substantially under-predicted. This location is, together with Cabauw, most strongly affected by anthropogenic emissions. In particular in winter, high concentrations are expected due to wood burning, in combination with stagnant conditions in the Po valley. For the site of Kosetice, the model shows a smaller underestimation in winter than in summer. For KPuszta, statistics before September are based on a small set of measurements and are therefore only indicative.

The correlation coefficients were reasonable, ranging on the average from 0.3 to 0.6 for the stations in Fig. $6 c$, and from 0.3 to 0.5 for the stations in Fig. 6d. A higher correlation was not always related to an accurate estimate of total particle number.

Modelled values were on the average within a factor of 2 of the measured values for the Aitken mode, compared to observed particle modes in the range $30-100 \mathrm{~nm}$ (results not shown here). However, the number of particles with a diameter $>100 \mathrm{~nm}$ was under-predicted, whereas the number of particles $<100 \mathrm{~nm}$ was in most cases over-predicted. Fountoukis et al. (2012) previously reported a similar result; a systematic under-prediction of the number of particles larger than $100 \mathrm{~nm}$, using the original EUCAARI emission inventory and another chemical-transport model.

These model evaluation studies indicate that the applied regional-scale modelling provides reasonably accurate results for PNCs in the size range larger than $30 \mathrm{~nm}$, in the presence of dominating anthropogenic emissions. In case of substantial biogenic contribution, the predicted PNCs will probably be underestimates. Clearly, the prediction of particle size distributions is a more challenging task, compared with the prediction of the PNCs integrated over all particle sizes.

\section{The spatial concentration distributions in Europe in 2005 and 2008}

The modelled European-scale PNCs for 2005 and for 2008 are presented in Fig. 7a-b. The differences of the concentrations between these two years have been presented in Fig. 7c-d.

The anthropogenic emissions of PN were assumed to be the same for these two years. However, for the emissions of 


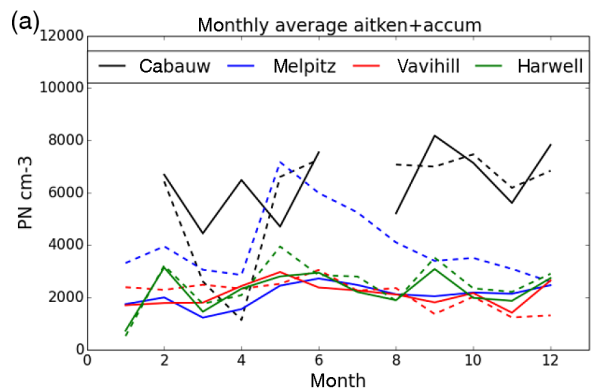

(c)

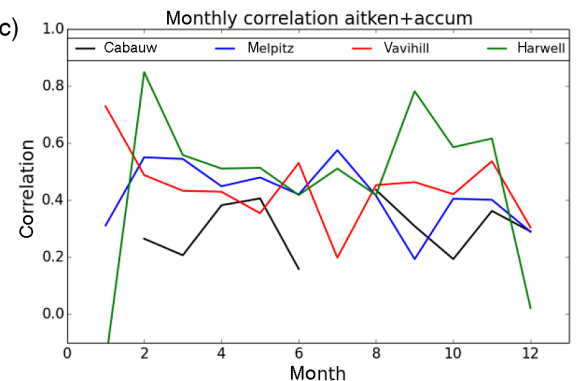

(b)

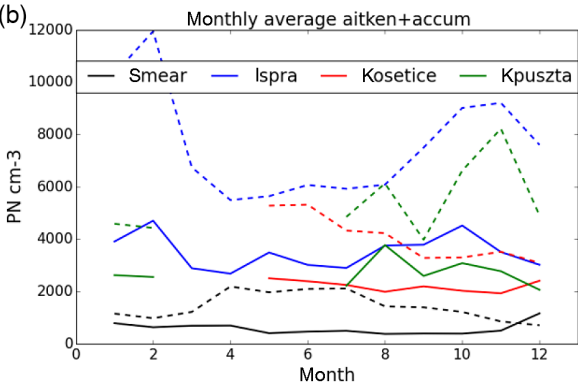

(d)

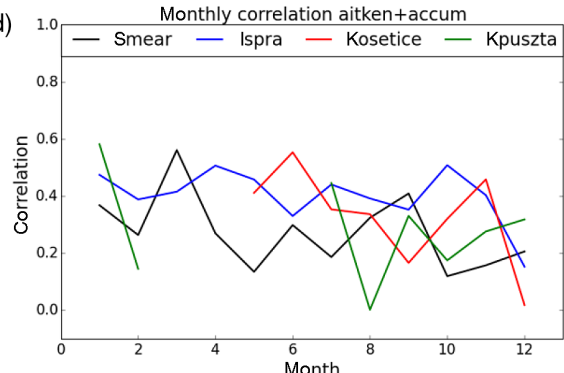

Figure 6. A comparison of the seasonal variation of the monthly averaged model predictions and observations of the particle number concentrations (particles $\mathrm{cm}^{-3}, \mathbf{a}-\mathbf{b}$ ), and the correlation coefficients of the hourly predicted and measured concentration values within each month, at eight selected measurement sites in 2008 (c-d). In the upper panels (a-b), the solid lines are model predictions, and the dotted lines are measurements. The modelled values are the predictions of the LOTOS-EUROS model. The nucleation mode has been excluded; the values correspond to the size fractions $30-250 \mathrm{~nm}$ and $10-1000 \mathrm{~nm}$ for the observations and the model computations, respectively.

gases, we used the MACC project emissions for the different years. The meteorological conditions and the natural emissions (which were influenced by meteorology) were also assumed to be different. During both years, the highest concentrations occurred at urban and industrialized areas, and along the most densely trafficked shipping lanes. Annual mean concentrations reached values of up to $10000 \mathrm{~cm}^{-3}$ for 2005 . For most regions, the PNCs were higher for 2005, compared with those for 2008 .

The largest concentration differences between the two target years were approximately $25 \%$. The fairly large differences of the concentrations near the western boundary of the domain are caused by the natural emissions, which were determined by the meteorological conditions. At other locations, differences are due to the combined effect of meteorology and decreased $\mathrm{SO}_{2}$ emissions; the emissions were lower for 2008.

\subsubsection{The influence of aerosol processes on an urban scale}

We did not include a treatment of aerosol processes to all of the urban-scale modelling systems used in this study. Instead, their influence was examined in a numerical study performed for Oslo in 2008. We have used a simplified aerosol process parametrization based on the more complex MAFOR aerosol process model and some experimental results. The numerical accuracy of the simplified model, as compared with the more complex model, was evaluated to be approximately $10 \%$.
The model needs as input values an initial size distribution, which was based on experimental data in Oslo, Rotterdam, and Helsinki. An initial size distribution ratio was defined as the initial fraction of the total PN concentration in each size bin $\left(\mathrm{PNC}_{1}, \mathrm{PNC}_{2}\right.$, and $\left.\mathrm{PNC}_{3}\right)$. These model input values have been presented in Table 2.

The impact of this parametrisation was tested in comparison with the measured data in Oslo for a 3-monthly period from January to April, 2008. In these computations, the upper limit values were used both for the coagulation coefficient and the dry deposition velocity, in order to evaluate the maximum possible effects due to these processes.

Use of the parametrisation resulted in lower PNC levels further from sources. At the urban background station in Oslo (Sofienbergparken), the above-mentioned parametrisation resulted in a maximum reduction of PN concentrations by approximately $45 \%$, compared to treating $\mathrm{PN}$ as a tracer. The range of this percentage value, allowing for the uncertainty of the simplified aerosol process modelling, can be considered to be approximately from 40 to $50 \%$. The impact of deposition was larger than that caused by coagulation; however, the influences of both processes were significant. The modelderived deposition and coagulation rates in the selected three size classes and the relevant timescales are presented in Table 2 . 

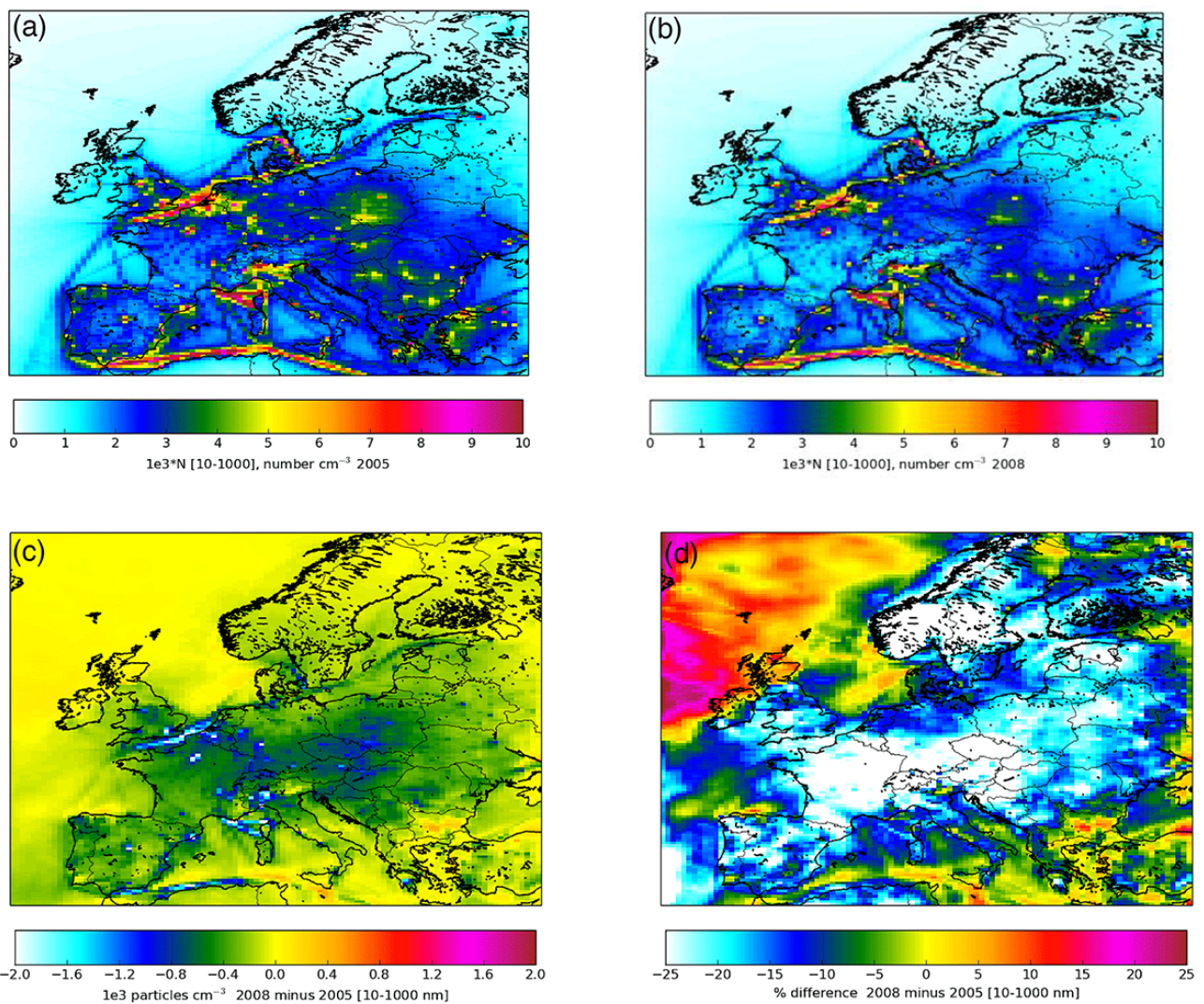

Figure 7. Predicted annual average particle number concentrations in Europe for 2005 (a) and for 2008 (b), and the difference of the concentrations between these two years in absolute (c) and relative units (d). The modelled particulate matter size range is from 10 to $1000 \mathrm{~nm}$. The unit in the legend is $10^{3}$ particles $\mathrm{cm}^{-3}$ in (a), (b), and (c), and percentage differences are presented in (d).

Table 2. Data and coefficients required for the implementation of the PNC parameterization used in Oslo. Typical predicted timescales associated with deposition and coagulation are also presented.

\begin{tabular}{lrrrrrr}
\hline $\begin{array}{l}\text { Size } \\
\text { class }\end{array}$ & $\begin{array}{r}\text { Size } \\
\text { range } \\
(\mathrm{nm})\end{array}$ & $\begin{array}{r}\text { Initial size } \\
\text { distribution } \\
\text { ratio }\end{array}$ & $\begin{array}{r}\text { Dry deposition } \\
\text { velocity } v_{\mathrm{d}} \\
\left(\mathrm{cm} \mathrm{s}^{-1}\right)\end{array}$ & $\begin{array}{r}\text { MAFOR } \\
\text { derived } K_{\mathrm{c}, i} \\
\left(\mathrm{~cm}^{3} \mathrm{no}^{-1} \mathrm{~s}^{-1}\right)\end{array}$ & $\begin{array}{r}\text { Typical } \\
\text { deposition time- } \\
\text { scale (h) }\end{array}$ & $\begin{array}{r}\text { Typical } \\
\text { coagulation time- } \\
\text { scale (h) }\end{array}$ \\
\hline $\mathrm{PNC}_{1}$ & $8.5-25$ & 0.79 & 0.904 & $6.31 \times 10^{-9}$ & 0.6 & 0.9 \\
$\mathrm{PNC}_{2}$ & $25-100$ & 0.20 & 0.202 & $5.58 \times 10^{-9}$ & 2.7 & 2.9 \\
$\mathrm{PNC}_{3}$ & $100-400$ & 0.01 & 0.032 & $8.82 \times 10^{-10}$ & 17 & 292 \\
\hline
\end{tabular}

\subsubsection{Predicted concentration distributions in the target cities}

The predicted annually averaged spatial concentration distributions in the target cities are presented in Fig. 8a-f. The same concentration legend is used for all the cities. The concentrations in various cities can therefore be inter-compared, allowing for the differences in the computational methods. The central area of London has been separately presented, by using a more closely spaced concentration legend.

The differences of the numerical results in the various cities are mainly due to the differences in the spatial distribution and strengths of emissions, the regional back- ground contributions, meteorological conditions, and other specific characteristics of the cities. Clearly, these differences are also partly caused by the inaccuracies and deficiencies of the methods. In particular, the concentration distribution for Athens was evaluated on a spatial resolution of $500 \mathrm{~m}$, which is coarser that the corresponding resolution used for the other cities; this tends to smooth out the maximum concentrations on finer spatial scales. Further, the modelling in this study did not explicitly allow for the influence of street canyons in all the target cities, except for the semi-empirical modelling of the effects of street canyons in Rotterdam. The predicted PNCs at street canyon locations, and more generally in the 

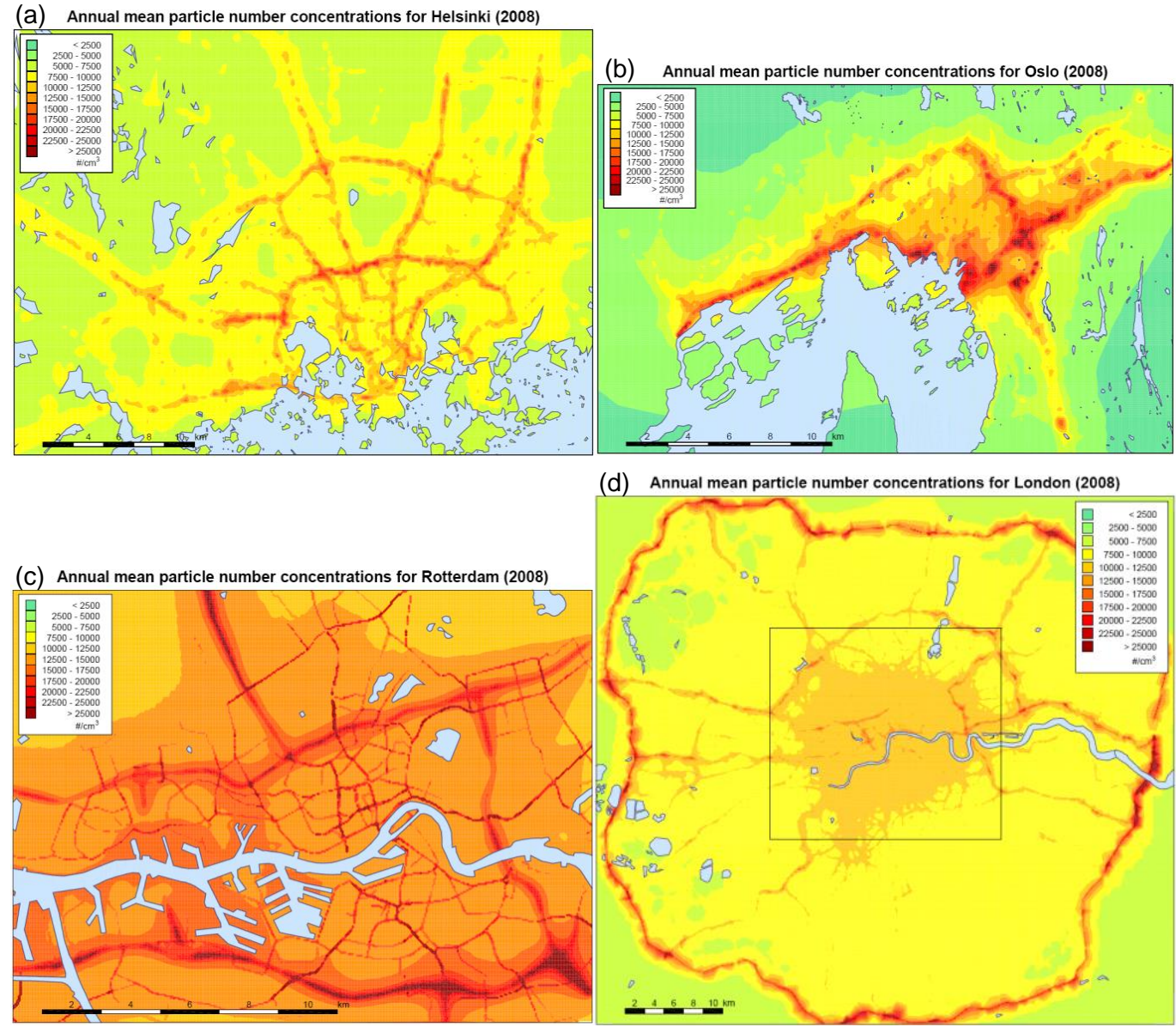

(e) Annual mean particle number concentrations for Athens (2008)

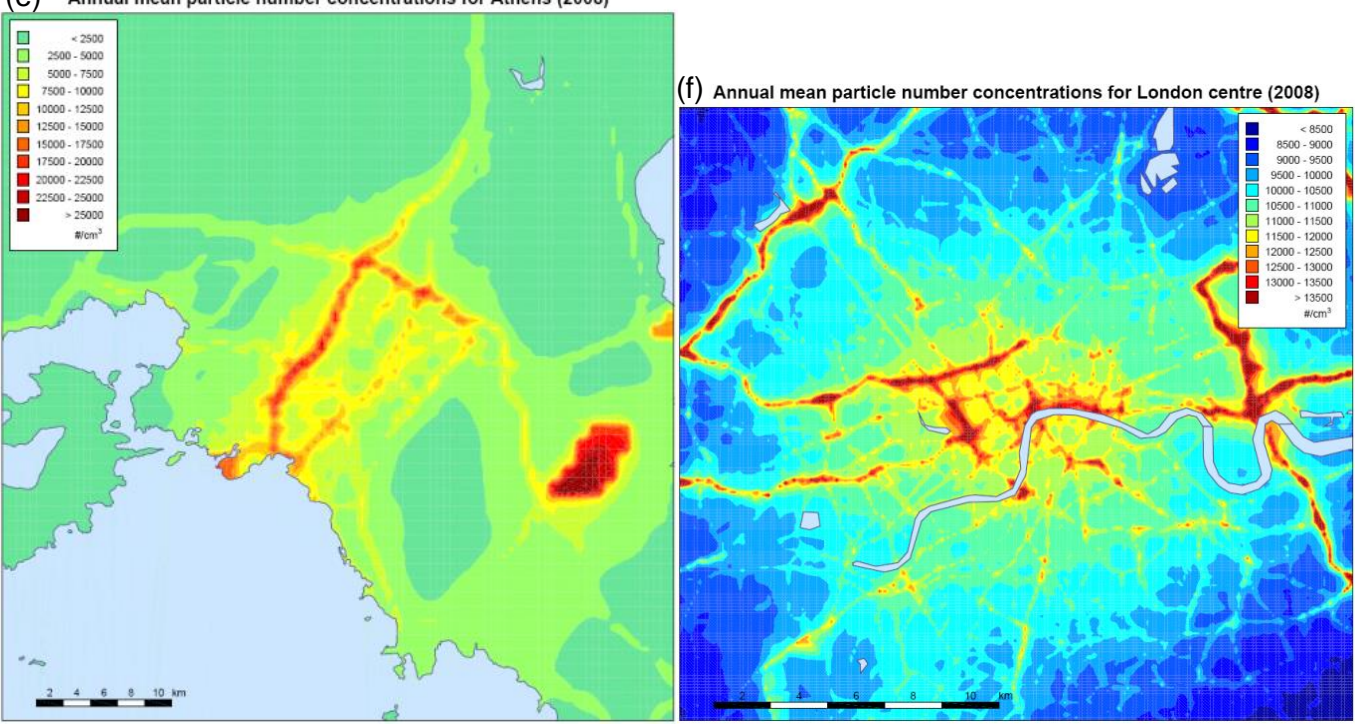

Figure 8. The predicted spatial distributions of particle number concentrations in the target cities in 2008. The cities in the top row are Helsinki and Oslo, in the middle row Rotterdam and London, and in the bottom row Athens and the centre of London (the location of which is shown in $\mathbf{d}$ as a rectangle). The concentration unit in all the legends is particles per $\mathrm{cm}^{3}$. The legends are identical for (a)-(e), but different for (f) (the centre of London). The water areas are presented in blue grey. 
vicinity of locations that are influenced by high buildings tend therefore to be under-predictions in this respect.

The maximum values of annual average PNCs were approximately 20000 in Helsinki, 30000 in Oslo, 30000 in Athens, and 50000 in Rotterdam and London. These values were relatively higher in London, due mainly to very high traffic flows along the most trafficked roads, and in Rotterdam, due to both high regional background and intensive urban traffic.

The locations of harbours and airports in the target cities have been presented in Fig. A1 in Appendix A. Also tunnel entrances have been presented for Oslo. In all cities, the most important emission category that influenced the spatial distributions of PNCs was vehicular traffic; the major traffic networks are clearly visible in all the target cities. For example, the main ring road or ring roads (for Helsinki, Oslo, London and Athens) or the main highways (for Rotterdam) surrounding the city centres are clearly visible. The concentrations were also elevated in the central areas of the cities. In Helsinki, Oslo, Rotterdam, and London, the highest concentrations occurred in the vicinity of the most densely trafficked ring roads, and near the junctions of such ring roads and other major roads. In Athens, the highest predicted concentrations of PNs occurred in the vicinity of the Athens International Airport.

The second most important urban source category was shipping and harbours. Their influences on the PNCs over land areas can be distinctly detected in the case of Oslo and Athens, and to a smaller extent also in Rotterdam. In Oslo, the higher concentrations in the vicinity of the harbours are also partly caused by the traffic tunnel entrances. It was assumed that there was no deposition of particles within the tunnels; therefore, all traffic-originated PNs within the tunnels were treated as emitted at these entrances. In Athens, there were substantially elevated PNCs near the main harbour regions (Piraeus and Rafina). For Helsinki, the shipping emissions have not been included in the PNC map shown in Fig. 8a; however, it was separately evaluated that their influences can be notable near the main harbour areas (Soares et al., 2014).

In a source apportionment study for London (Beddows et al., 2015), it was shown that the urban traffic and the urban background contributed 45 and $43 \%$, respectively, to the total PNC at an urban background station. Further, according to the London Atmospheric Emission Inventory (GLA, 2010), shipping is responsible for a negligible fraction of the total PM mass-based emissions. We therefore conclude that considering the annual average concentration levels for the whole of London, shipping along the River Thames and the related harbour activities probably cause a small or negligible impact on the overall PNCs.

Although the harbours in the vicinity of Rotterdam are amongst the largest in Europe, the influence of harbour activities was only modestly detectable in Fig. 8c. The main reason for this was the fact that the most densely trafficked harbours in that region are located outside the city of Rotterdam. The harbours within the city of Rotterdam are located to the south and north of the river Nieuwe Maas, which flows through the centre of Rotterdam. These urban harbours serve mainly inland shipping. The larger harbours serving sea going vessels are located at a distance of $5-10 \mathrm{~km}$ to the west of the centre of Rotterdam, near the coast of the North Sea. The harbours within the city of Rotterdam are also dispersed on a relatively wide region on both sides of the river; this tends to spatially smooth out concentration hotspots.

A potentially important source is also vehicular traffic to the airports and aviation. In Athens, there were substantially elevated PNCs near the Athens International Airport, located to the east from the centre of the city (it is clearly visible in Fig. 8e). Detailed computations showed that aviation emissions were responsible for the largest share of the concentrations within this airport and in its immediate vicinity. The influence of the Heathrow airport in London is also visible in the PNC map (near the outer ring road on the western part of the city). However, these higher predicted concentrations were caused by the emissions from the congested roads leading to Heathrow airport. The emissions originating from aviation in London were included in the regional background concentrations (the LOTOS-EUROS predictions), but not explicitly in the urban-scale computations. The Helsinki-Vantaa airport is only slightly detectable (to the north of the outer ring road, in the northern part of the metropolitan area). The airport in Oslo is outside the modelled domain. The influence of the Rotterdam The Hague Airport is not visible; it is a fairly small airport.

There are also some other significant source categories, such as major refineries in the vicinity of Rotterdam; however, these were not located within the modelled urban domain. Especially in Oslo, the small-scale combustion in households can also be an important source in residential regions in winter.

\subsection{Evaluation of model predictions against measured data in the target cities}

The model predictions were compared with the available PNC measurements in the target cities. Such measured data were available in four of the cities, as presented in Table 3.

The predictions and measurements were compared at two stations, representing urban background and urban traffic environments, in three cities, viz. Oslo, Rotterdam, and London. In the case of Helsinki, such comparisons were performed only at one station (Ring road 1, Malmi, urban traffic) for 2012. The comparisons were performed for different years in Rotterdam (2011) and in Helsinki (2012), as the relevant measured data were not available for those cities in 2008.

The comparison in the case of annual averages is also presented graphically, in Fig. 9. The predicted concentrations consist of the regional background and the local urban contri- 
Table 3. The comparison of measured and predicted PNCs in four target cities. IA is the index of agreement and FB is the fractional bias. NA refers to data or evaluation measures that were not available.

\begin{tabular}{|c|c|c|c|c|c|c|c|}
\hline City & Name of station & $\begin{array}{l}\text { Classification of } \\
\text { station }\end{array}$ & Period & $\begin{array}{l}\text { Mean of the } \\
\text { observed values } \\
\left(10^{3} \text { particles }\right. \\
\left.\mathrm{cm}^{-3}\right)\end{array}$ & $\begin{array}{l}\text { Mean of the } \\
\text { predicted } \\
\text { values } \\
\left(10^{3} \text { particles }\right. \\
\left.\mathrm{cm}^{3}\right)\end{array}$ & $\begin{array}{l}\text { IA (based } \\
\text { on the } \\
\text { hourly } \\
\text { means) }\end{array}$ & FB \\
\hline \multirow[t]{2}{*}{ Helsinki } & SMEAR III, Kumpula & Urban background & Whole year 2012 & 7.1 & NA & NA & NA \\
\hline & Ring road I & Urban traffic & Whole year 2012 & 19.5 & 20.0 & 0.75 & +0.02 \\
\hline \multirow[t]{2}{*}{ Oslo } & Sofienbergparken & Urban background & $\begin{array}{l}\text { Three months, } \\
\text { Jan-Mar } 2008\end{array}$ & 9.3 & 10.8 & 0.77 & +0.15 \\
\hline & Smestad & Urban Traffic & $\begin{array}{l}\text { Three months, } \\
\text { Jan-Mar } 2008\end{array}$ & 24.0 & 19.8 & 0.79 & -0.19 \\
\hline \multirow[t]{2}{*}{ Rotterdam } & Zwartewaalstraat & Urban background & $\begin{array}{l}\text { Whole year } \\
2011\end{array}$ & 14.5 & 10.1 & NA & -0.22 \\
\hline & $\begin{array}{l}\text { Rotterdam, } \\
\text { Bentinckplein }\end{array}$ & Urban traffic & $\begin{array}{l}\text { Whole year } \\
2011\end{array}$ & 17.7 & 20.1 & NA & +0.20 \\
\hline \multirow[t]{2}{*}{ London } & North Kensington & Urban background & $\begin{array}{l}\text { Whole year } \\
2008\end{array}$ & 14.0 & 10.8 & NA & -0.26 \\
\hline & Marylebone Road & Urban traffic & $\begin{array}{l}\text { Whole year } \\
2008\end{array}$ & 36.7 & 15.7 & NA & -0.81 \\
\hline
\end{tabular}

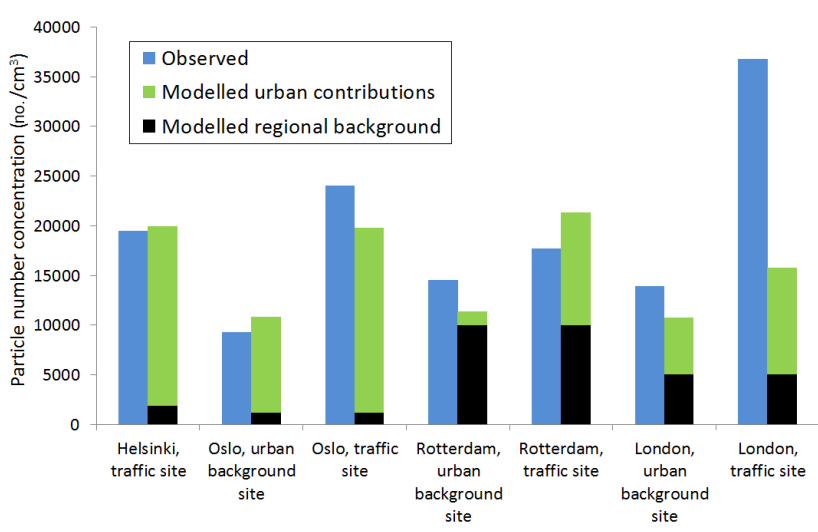

Figure 9. Comparison of the predicted and measured annual average particle number concentrations in four cities. The total predicted concentration is the sum of regional background and urban contributions. The names of the stations have been specified in Table 3 .

butions. The regional background values presented in the figure are the predictions of the LOTOS-EUROS model in the surroundings of the cities, either the original predictions (for Helsinki and Rotterdam) or scaled using relevant regional background measurements (for Oslo and London).

The regional background concentrations were clearly lower than the contributions originating from urban sources in Helsinki and Oslo, and lower (for traffic site) or almost equal (urban background) in London. However, for Rotterdam the regional background was the largest contributor (for urban background) or responsible for almost half of the total concentration (urban traffic site). This result was to be expected, as Rotterdam is surrounded by a high population density and several intensive emission sources (such as other major cities, refineries and major harbours). The uncertainties caused by the regional-scale modelling have therefore a relatively smaller effect in Helsinki, Oslo, and London (but vice versa for Rotterdam), compared with the uncertainties associated with the urban-scale modelling.

The corresponding results for Athens are not presented in Fig. 9, as the experimental data was not available for 2008. The representative annual average of the urban background of PNC in Athens, predicted at the station of Nea Smyrni, was $6.8 \times 10^{3} \mathrm{~cm}^{-3}$. A characteristic annual average PNC predicted at an urban traffic station, Athinas, was $12.2 \times 10^{3} \mathrm{~cm}^{-3}$. The measured regional background of PNC was $1.8 \times 10^{3} \mathrm{~cm}^{-3}$. However, the predicted values at specific point locations in Athens are not directly comparable with those in the other cities, due to the more coarse resolution of the computations. The air quality stations in traffic environments in the Greater Athens area are also not located in the immediate vicinity of the major highways.

The predicted and measured annual averages agreed within approximately $\leq 26 \%$ (measured as fractional biases), except for the traffic station in London. As expected, the agreement of annual average concentration values was better at urban background stations compared with urban traffic stations in Oslo and London; however, these agreements were not substantially different in Rotterdam. The urban traffic station in London is Marylebone Road, which is located in a street canyon and has continuously severe traffic congestion. The measured concentration at the Marylebone Road station is substantially higher than the predicted value. The lower predicted concentration values are probably mainly caused by the fact that the computations in this study did not allow for the effects due to street canyons for London. 
It was possible to evaluate the agreement of the measured and predicted hourly time series of PNCs at three stations located in two cities, Oslo and Helsinki (cf. Table 3). The period of these comparisons was 1 year in the case of Helsinki, and 3 months in the case of Oslo. The indexes of agreement (IA) for these comparisons were 0.75 for the annual time period in Helsinki, and 0.77 and 0.79 for the 3-monthly periods in Oslo; these values indicate a fairly good agreement of measurements and predictions. However, the computational methods also influence the values of the IA's. In the case of Oslo, the regional background values and local urban contributions were separately modelled, whereas for Helsinki, the predicted values contain measured urban background PNC values and the predicted local contributions. The measured annual average of the urban background of the PNC (at the site of Kumpula) was $7.1 \times 10^{3} \mathrm{~cm}^{-3}$ and the modelled contribution originating from urban vehicular sources was $12.9 \times 10^{3} \mathrm{~cm}^{-3}$.

In general, we evaluate that for Helsinki, Oslo, and London, the largest contributors to the differences of predictions and measurements are (i) the uncertainties of the urbanscale emission inventories, and (ii) the uncertainties associated with the urban dispersion modelling systems. For cities located in highly urbanized regions, such as Rotterdam, the uncertainties of evaluating regional background can be even more important. Clearly, sources or source categories that are missing from the computations can also have a significant effect. For instance, we performed computations for Rotterdam, neglecting the contributions from shipping and harbours. The fractional biases (FBs) were -0.36 (including shipping that was -0.22 ) and +0.13 (including shipping +0.20 ).

\section{Conclusions}

We have presented the results of the modelling of PNCs in five European cities in 2008. Novel emission inventories of particle numbers have been compiled both on urban and European scales (the latter is called the TRANSPHORM inventory). It has not previously been possible to conduct such computations on a European scale, due to the deficiencies of the previously available emission inventories. The TRANSPHORM PN emission inventory was based on a previous inventory that was compiled in the EUCAARI project (Kulmala et al., 2011). The new inventory focused on improving the representation of the emissions of the transport sector; major improvements were made to the previous inventory in this respect. The previous emission inventory was also substantially re-structured and improved for particulate matter emissions.

However, there are still unresolved issues on PN emissions. The semi-volatile particulate matter should also be allowed for, in addition to solid state particles. Another challenge is to allow for the short-term temporal transformations of particulate matter, after the exhaust of pollutants from an engine or an industrial process. PNC is not a conserved quantity, and the emission values are therefore dependent on the detailed definition of emissions; especially on the assumed spatial distance from the emission source. Clearly, the transformation is dependent on ambient conditions, especially on the ambient air temperature. The values of measured PN emissions are also dependent on the selected lower particulate matter limit; this is commonly determined by the capabilities of the experimental techniques. The impacts of fuel quality and the sulfur content of fuels on PN emissions are also not currently sufficiently understood.

We have also compiled detailed and extensive urban-scale emission inventories in the five target cities. However, the information regarding some source sectors is still missing. The present knowledge is also not sufficiently accurate, especially for shipping and small-scale combustion, and in terms of various environmental conditions. In future work, an indepth inter-comparison of such urban emission inventories would also be valuable, in terms of both the physical assumptions and the numerical emission values.

We have conducted dispersion modelling on both European and urban scales. The European-scale computations included aerosol process modelling; however, it was not possible to include a detailed treatment of aerosol processes to all of the urban-scale modelling systems. Instead, the influence of coagulation and deposition was examined numerically for the background air pollution in Oslo in 2008. These processes were estimated to reduce the background air PNCs maximally by approximately $40-50 \%$ in the considered environmental conditions. However, the above-mentioned evaluation did not allow for the evaporation and condensation processes; these may also significantly influence the ambient concentrations. The urban-scale modelling in this study also did not explicitly allow for the influence of urban buildings and other structures.

In all of the target cities, the highest concentrations occurred in the vicinity of the most densely trafficked roads, and near the junctions of such roads and other major roads. The concentrations were also elevated in the city centres. The influence of shipping and harbours was also significant for all the target cities, except for London. Three of the target cities are located on the seaside (Helsinki, Oslo, and Athens), and two are situated along major rivers (Rotterdam and London). The regional background concentrations were an important factor for London, and the largest factor for Rotterdam. In Oslo, the PNCs were also enhanced near the road tunnel entrances.

The predicted and measured annual average PNCs in four cities agreed within approximately $\leq 26 \%$, except for one traffic station in London. We consider this agreement to be reasonable, considering the many potential uncertainties associated with the PNC modelling. The indexes of agreement (IA) for the comparisons of hourly measured and predicted time series in Oslo and Helsinki ranged from 0.75 to 0.79 , in- 
dicating a fairly good agreement. However, the amount of experimental data that could be used for model evaluation was modest: only one or two stations for each city, and no relevant data were available for Athens. More long-term hourly measurements of PNCs would therefore be valuable for a more thorough model evaluation in various urban locations. 
Appendix A: The locations of major harbours, airports, and tunnel entrances in the target cities
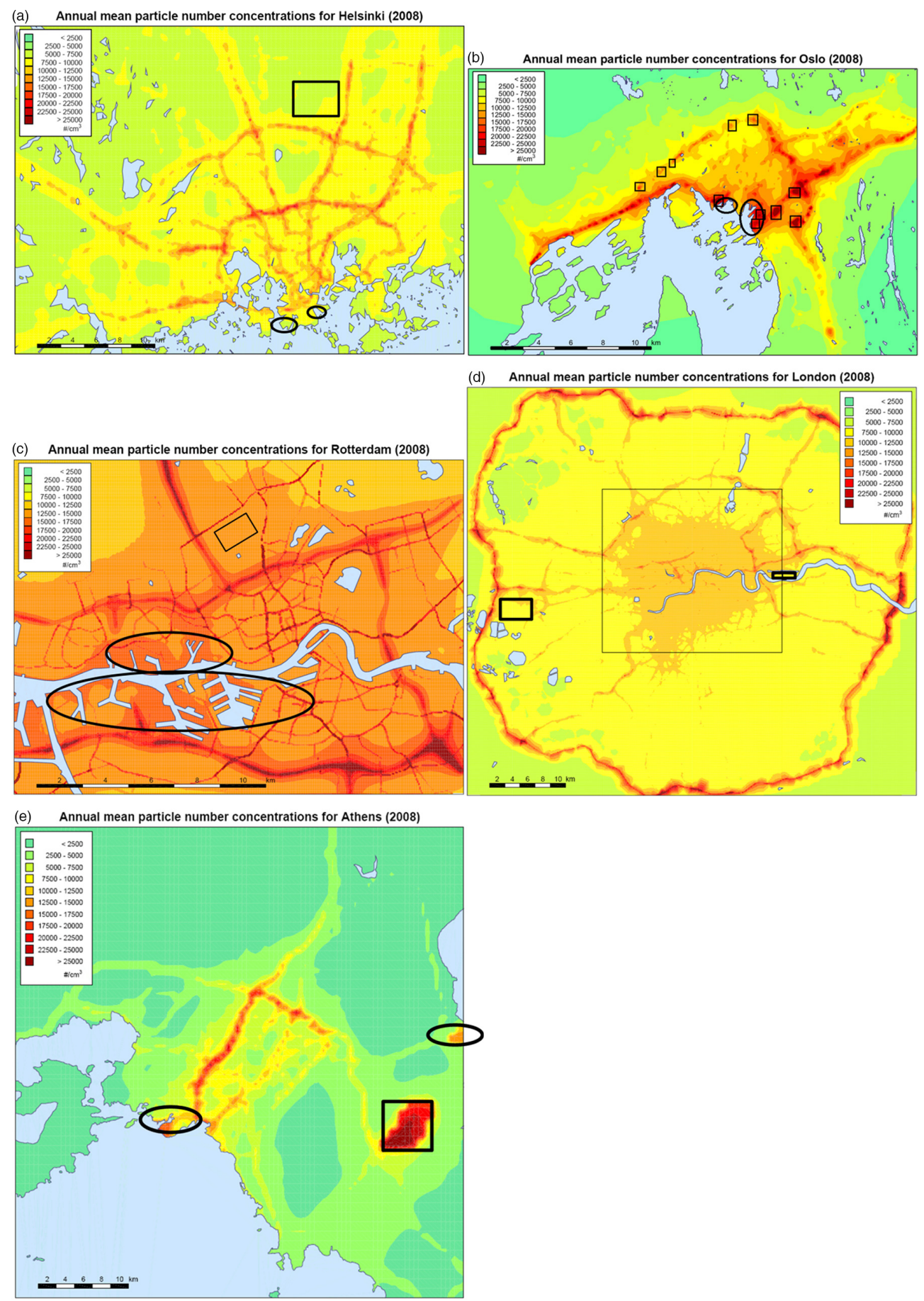

Figure A1. The locations of major harbours, airports, and tunnel entrances in the target cities. The harbour areas have been marked with oval shapes. The airports have been marked with rectangles, except for Oslo, for which the rectangles correspond to the locations of the tunnel entrances. The geographical areas denoted by the shapes in the panels are approximates. (a)-(e) correspond to Helsinki, Oslo, Rotterdam, London, and Athens, respectively. 


\section{Code availability}

The computer code of the LOTOS-EUROS model can be made available upon request (contact Astrid Manders at astrid.manders@tno.nl). The code is written in FORTRAN 90 and uses NetCDF libraries and python scripts.

The access to the CAR-FMI model for educational and non-commercial research use can be granted after signing a collaborative agreement with the Finnish Meteorological Institute (contact Jaakko Kukkonen at jaakko.kukkonen@fmi.fi). The code is written in FORTRAN 77.

The computer code of the EPISODE model can be made available upon request (contact Leonor Tarrason at leonor.tarrason@nilu.no). The code is written in FORTRAN 90.

The OSCAR model can be configured for any urban area in collaboration with the Centre for Atmospheric and Instrumentation Research (CAIR) at the University of Hertfordshire, UK. Access to the model for educational and noncommercial research use can be granted after signing a collaborative agreement with the University of Hertfordshire. The code has been developed to assess air quality and exposure to air pollution at local scales across cities (contact Ranjeet S Sokhi at r.s.sokhi@ herts.ac.uk). The model code is written in FORTRAN 90, except for emission model, which is written in Matlab.

The MEMO and MARS-aero models can be obtained for educational and non-commercial research use, after signing an end-user license agreement from the Aristotle University of Thessaloniki (contact George Tsegas at gtseg@aix.meng.auth.gr). The code is written in FORTRAN 95 and uses OpenMP and MPI directives.

Acknowledgements. This work was mainly funded by EU Seventh Framework Programme - (ENV.2009.1.2.2.1) project TRANSPHORM. We also wish to thank for funding of the Academy of Finland for "The Influence of Air Pollution, Pollen and Ambient Temperature on Asthma and Allergies in Changing Climate (APTA)", Nordforsk under the Nordic Programme on Health and Welfare for the project \#75007 "Understanding the link between Air pollution and Distribution of related Health Impacts and Welfare in the Nordic countries (NordicWelfAir)", and Academy of Finland via The Centre of Excellence in Atmospheric Science - From Molecular and Biological processes to The Global Climate (272041). We thank Anu Kousa, Helsinki Region Environmental Services Authority (HSY), for the particle number concentration data from the traffic site in Helsinki. Mari Kauhaniemi and Juha Nikmo are thanked for the processing of the data and results.

Edited by: J. Williams

\section{References}

Asmi, A., Wiedensohler, A., Laj, P., Fjaeraa, A.-M., Sellegri, K., Birmili, W., Weingartner, E., Baltensperger, U., Zdimal, V., Zikova, N., Putaud, J.-P., Marinoni, A., Tunved, P., Hansson, H.C., Fiebig, M., Kivekäs, N., Lihavainen, H., Asmi, E., Ulevicius, V., Aalto, P. P., Swietlicki, E., Kristensson, A., Mihalopoulos, N., Kalivitis, N., Kalapov, I., Kiss, G., de Leeuw, G., Henzing, B., Harrison, R. M., Beddows, D., O’Dowd, C., Jennings, S. G., Flentje, H., Weinhold, K., Meinhardt, F., Ries, L., and Kulmala, M.: Number size distributions and seasonality of submicron particles in Europe 2008-2009, Atmos. Chem. Phys., 11, 5505-5538, doi:10.5194/acp-11-5505-2011, 2011.

Atkinson, R. W., Fuller, G. W., Anderson, H. R., Harrison, R. M., and Armstrong, B.: Urban ambient particle metrics and health: a time series analysis, Epidemiology, 21, 501-511, 2010.

Beddows, D. C. S., Harrison, R. M., Green, D. C., and Fuller, G. W.: Receptor modelling of both particle composition and size distribution from a background site in London, UK, Atmos. Chem. Phys., 15, 10107-10125, doi:10.5194/acp-15-10107-2015, 2015.

Beelen, R., Voogt, M., Duyzer, J., Zandveld, P., and Hoek, G.: Comparison of the performances of land-use regression modelling and dispersion modelling in estimating small-scale variations in long-term air pollution concentrations in a Dutch urban area, Atmos. Environ., 44, 4614-4621, 2010.

Bualert, S.: Development and Application of an Advanced Gaussian Urban Air Quality Model, University of Hertfordshire, UK, 2002.

Buzea, C., Pacheco Blandino, I. I., and Robbie, K.: Nanomaterials and nanoparticles: Sources and toxicity, Biointerphases, 2, 17172, 2007.

Daher, N., Hasheminassab, S., Shafer, M. M., Schauer, J. J., and Sioutas, C.: Seasonal and spatial variability in chemical composition and mass closure of ambient ultrafine particles in the megacity of Los Angeles, Environmental Science: Processes \& Impacts, 15, 283-295, doi:10.1039/C2EM30615H, 2013.

Delfino, R. J., Sioutas, C., and Malik, S.: Potential role of ultrafine particles in associations between airborne particle mass and cardiovascular health, Environ. Health Persp., 113, 934-946, 2005.

Denier van der Gon, H. A. C. and Hulskotte, J.: Methodologies for estimating shipping emissions in the Netherlands A documentation of currently used emission factors and related activity data, PBL Report 500099012, ISSN1875-2322, Bilthoven 2010, available at: http://www.pbl.nl/en/publications/2010/Methodologiesfor-estimating-shipping-emissions-in-the-Netherlands (last access: 1 February 2016), 2010.

Denier van der Gon, H. A. C., Visschedijk, A. J. H., Johansson, C., Ntziachristos, L., and Harrison, R. M.: Size-resolved Pan-European Anthropogenic Particle Number Inventory, Conference proceedings of International Aerosol Conference 2010, 29 August-3 September 2010, Helsinki, Finland, 2010a.

Denier van der Gon, H. A. C., Visschedijk, A., van der Brugh, H., and Dröge, R.: A high resolution European emission data base for the year 2005, A contribution to UBA-Projekt PAREST: Particle Reduction Strategies, TNO report TNO-034-UT-201001895_RPT-ML, Utrecht, 2010b.

Denier van der Gon, H. A. C., Visschedijk, A. J. H., Kuenen, J., Schieberle, C., Vouitsis, I., Samaras, Z., Moldanova, J., and Petzold, A.: European particle number emissions for 2005, 2020 and 2030 with special emphasis on the transport sector, 9th Inter- 
national Conference on Air Quality - Science and Application, Garmisch-Partenkirchen, Germany, 2014.

Eerens, H. C., Sliggers, C. J., and van den Hout, K. D.: The CAR model: the Dutch method to determine city street air quality, Atmos. Environ., 27B, 389-399, 1993.

Fiebig, M., Wiartalla, A., Holderbaum, B., and Kiesow, S.: Particulate emissions from diesel engines: correlation between engine technology and emissions, Journal of Occupational Medicine and Toxicology, 9, 6, doi:10.1186/1745-6673-9-6, 2014.

Fountoukis, C., Riipinen, I., Denier van der Gon, H. A. C., Charalampidis, P. E., Pilinis, C., Wiedensohler, A., O'Dowd, C., Putaud, J. P., Moerman, M., and Pandis, S. N.: Simulating ultrafine particle formation in Europe using a regional CTM: contribution of primary emissions versus secondary formation to aerosol number concentrations, Atmos. Chem. Phys., 12, 86638677, doi:10.5194/acp-12-8663-2012, 2012.

Franck, U., Odeh, S., Wiedensohler, A., Wehner, B., and Herbarth, O.: The effect of particle size on cardiovascular disorders - the smaller the worse, Sci. Total Environ., 409, 4217-4221, 2011.

González, Y. and Rodríguez, S.: A comparative study on the ultrafine particle episodes induced by vehicle exhaust: A crude oil refinery and ship emissions, Atmos. Res., 120-121, 43-54, 2013.

Gidhagen, L., Johansson, C., Langner, J., and Foltescu, V. L.: Urban scale modeling of particle number concentration in Stockholm, Atmos. Environ., 39, 1711-1725, 2005.

Giechaskiel, B., Mamakos, A., Andersson, J. , Dilara, P., Martini, G., Schindler, W., and Bergmann, A.: Measurement of Automotive Nonvolatile Particle Number Emissions within the European Legislative Framework: A Review, Aerosol Sci. Tech., 46, 719749, doi:10.1080/02786826.2012.661103, 2012.

GLA: The London Atmospheric Emissions Inventory 2008, available at: http://data.london.gov.uk/laei-2008 (last access: 1 February 2016), 2010.

Glasius, M., Ketzel, M., Wåhlin, P., Bossi, R., Stubkjær, J., Hertel, O., and Palmgren, F.: Characterization of particles from residential wood combustion and modelling of spatial variation in a low-strength emission area, Atmos. Environ., 42, 8686-8697, 2008.

Gkatzoflias, D., Kouridis, C., Ntziachristos, L., and Samaras, Z.: "COPERT 4, Computer Programme to Calculate Emissions from Road Transport, User Manual”, European Environment Agency, v9.0, 2012.

Guenther, A., Hewitt, C. N., Erickson, D., Fall, R., Geron, C., Graedel, T., Harley, P., Klinger, L., Lerdau, M., McKay, W. A., Pierce, T., Scholes, B., Steinbrecher, R., Tallamraju, R., Taylor, J., and Zimmermann, P.: A global model of natural volatile organic compound emissions, J. Geophys. Res., 100, 8873-8892, 1995.

Härkönen, J., Valkonen, E., Kukkonen, J., Rantakrans, E., Lahtinen, K., Karppinen, A., and Jalkanen, L.: A model for the dispersion of pollution from a road network. Finnish Meteorological Institute, Publications on Air Quality 23, Helsinki, 34 pp., 1996.

Hedberg, E., Kristensson, A., Ohlsson, M., Johansson, C., Johansson, P. A., Swietlicki, E., Veselya, V., Wideqvista, U., and Westerholm, R.: Chemical and physical characterization of emissions from birch wood combustion in a wood stove, Atmos. Environ., 36, 4823-4837, 2002.

Helmis, C. G., Moussiopoulos, N., Flocas, H. A., Sahm, P., Assimakopoulos, V. D., Naneris, C., and Maheras, P.: Estimation of transboundary air pollution on the basis of synoptic scale weather types, Int. J. Climatol., 23, 405-416, 2003.

Hoek, G., Boogaard, H., Knol, A., Hartog de, J., Slottie, P., Ayres, J. G., Borm, P., Brunekreef, B., Donaldson, K., Forastiere, F., Holgate, S., Kreyling, W. G., Nemery, B., Pekkanen, J., Stone, V., Wichmann, E., and Sluis van der, J.: Concentration response functions for ultrafine particles and all-cause mortality and hospital admissions: Results of an European expert panel elicitation, Environ. Sci. Technol., 44, 476-482, 2010.

Hsu, H.-H., Adamkiewicz, G., Houseman, A. E., Spengler, J. D., and Levy, J. I.: Using mobile monitoring to characterize roadway and aircraft contributions to ultrafine particle concentrations near a mid-sized airport, Atmos. Environ., 89, 688-695, 2014.

Hussein, T., Kukkonen, J., Korhonen, H., Pohjola, M., Pirjola, L., Wraith, D., Härkönen, J., Teinilä, K., Koponen, I. K., Karppinen, A., Hillamo, R., and Kulmala, M.: Evaluation and modeling of the size fractionated aerosol particle number concentration measurements nearby a major road in Helsinki - Part II: Aerosol measurements within the SAPPHIRE project, Atmos. Chem. Phys., 7, 4081-4094, doi:10.5194/acp-7-4081-2007, 2007.

INRO: EMME/2 User's Manual, INRO Consultants Inc., Montreal, Canada, 1994.

Jalkanen, J.-P., Johansson, L., Kukkonen, J., Brink, A., Kalli, J., and Stipa, T.: Extension of an assessment model of ship traffic exhaust emissions for particulate matter and carbon monoxide, Atmos. Chem. Phys., 12, 2641-2659, doi:10.5194/acp-12-26412012, 2012.

Järvi, L., Hannuniemi, H., Hussein, T., Junninen, H., Aalto, P. P., Hillamo, R., Mäkelä, T., Keronen, P., Siivola, E., Vesala, T., and Kulmala, M.: The urban measurement station SMEAR III: Continuous monitoring of air pollution and sufrace-atmosphere interactions in Helsinki, Finland, Boreal Environ. Res., 14, 86-109, 2009.

Johansson, L., Jalkanen, J.-P., Kalli, J., and Kukkonen, J.: The evolution of shipping emissions and the costs of regulation changes in the northern EU area, Atmos. Chem. Phys., 13, 11375-11389, doi:10.5194/acp-13-11375-2013, 2013.

Jones, A. M. and Harrison, R. M.: Estimation of the emission factors of particle number and mass fractions from traffic at a site where mean vehicle speeds vary over short distances, Atmos. Environ., 40, 7125-7137, 2006.

Kalafut-Pettibone, A. J., Wang, J., Eichinger, W. E., Clarke, A., Vay, S. A., Blake, D. R., and Stanier, C. O.: Size-resolved aerosol emission factors and new particle formation/growth activity occurring in Mexico City during the MILAGRO 2006 Campaign, Atmos. Chem. Phys., 11, 8861-8881, doi:10.5194/acp-11-88612011, 2011.

Kalivitis, N., Birmili, W., Stock, M., Wehner, B., Massling, A., Wiedensohler, A., Gerasopoulos, E., and Mihalopoulos, N.: Particle size distributions in the Eastern Mediterranean troposphere, Atmos. Chem. Phys., 8, 6729-6738, doi:10.5194/acp-8-67292008, 2008.

Karl, M., Gross, A., Pirjola, L., and Leck, C.: A new flexible multicomponent model for the study of aerosol dynamics in the marine boundary layer, Tellus B, 63, 1001-1025, doi:10.1111/j.16000889.2011.00562.x, 2011.

Karppinen, A., Joffre, S. M., and Kukkonen, J.: The refinement of a meteorological preprocessor for the urban environment, Int. J. Environ. Pollut., 14, 565-572, 2000. 
Kauhaniemi, M., Karppinen, A., Härkönen, J., Kousa, A., Alaviippola, B., Koskentalo, T., Aarnio, P., Elolähde, T., and Kukkonen, J.: Evaluation of a modelling system for predicting the concentrations of $\mathrm{PM}_{2.5}$ in an urban area, Atmos. Environ., 42, 45174529, 2008.

Kerminen, V.-M., Pakkanen, T. A., Mäkelä, T., Hillamo, R. E., Sillanpää, M., Rönkkö, T., Virtanen, A., Keskinen, J., Pirjola, L., Hussein, T., and Hämeri, T.: Development of particle size distribution near a major road in Helsinki during an episodic inversion situation, Atmos. Environ., 41, 1759-1767, 2007.

Ketzel, M. and Bercowicz, R.: Modelling the fate of ultrafine particles from exhaust pipe to rural background: an analysis of time scales for dilution, coagulation and deposition, Atmos. Environ., 38, 2639-2652, 2004.

Ketzel, M., Wåhlin, P., Kristensson, A., Swietlicki, E., Berkowicz, R., Nielsen, O. J., and Palmgren, F.: Particle size distribution and particle mass measurements at urban,near-city and rural level in the Copenhagen area and Southern Sweden, Atmos. Chem. Phys., 4, 281-292, doi:10.5194/acp-4-281-2004, 2004.

Keuken, M. P., Henzing, J. S., Zandveld, P., van den Elshout, S., and Karl, M.: Dispersion of particle numbers and elemental carbon from road traffic, a harbor and an airstrip in the Netherlands, Atmos. Environ., 54, 320-327, 2012.

Keuken, M. P., Moerman, M., Zandveld, P., Henzing, J. S., and Hoek, G.: Total and size-resolved particle number and black carbon concentrations in urban areas near Schiphol airport (the Netherlands), Atmos. Environ., 104, 132-142, 2015a.

Keuken, M. P., Moerman, M., Zandveld, P., and Henzing, J. S.: Total and size-resolved particle number and black carbon concentrations near an industrial area, Atmos. Environ., 122, 196-205, $2015 b$.

Kittelson, D. B., Watts, W. F., and Johnson, J. P.: Nanoparticle emissions on Minnesota highways, Atmos. Environ., 38, 9-19, 2004.

Kittelson D. B., Watts W. F., and Johnson, J. P.: On-road and laboratory evaluation of combustion aerosols - Part 1: Summary of diesel engine results, Aerosol Sci., 37, 913-930, 2006.

Kioutsioukis, I., Kouridis, Ch., Gkatzoflias, D., Dilara, P., and Ntziachristos, L.: Uncertainty and Sensitivity Analysis of National Road Transport Inventories Compiled with COPERT 4, Procedia Social and Behavioral Sciences, 2, 7690-7691, 2010.

Klose, S., Birmili, W., Voigtländer, J., Tuch, T., Wehner, B., Wiedensohler, A., and Ketzel, M.: Particle number emissions of motor traffic derived from street canyon measurements in a Central European city, Atmos. Chem. Phys. Discuss., 9, 3763-3809, doi:10.5194/acpd-9-3763-2009, 2009.

Kukkonen, J., Härkönen, J., Walden, J., Karppinen, A., and Lusa, K.: Evaluation of the CAR-FMI Model Against Measurements Near a Major Road, Atmos. Environ., 35, 949-960, doi:10.1016/S1352-2310(00)00337-X, 2001.

Kukkonen, J., Olsson, T., Schultz, D. M., Baklanov, A., Klein, T., Miranda, A. I., Monteiro, A., Hirtl, M., Tarvainen, V., Boy, M., Peuch, V.-H., Poupkou, A., Kioutsioukis, I., Finardi, S., Sofiev, M., Sokhi, R., Lehtinen, K. E. J., Karatzas, K., San José, R., Astitha, M., Kallos, G., Schaap, M., Reimer, E., Jakobs, H., and Eben, K.: A review of operational, regional-scale, chemical weather forecasting models in Europe, Atmos. Chem. Phys., 12, 1-87, doi:10.5194/acp-12-1-2012, 2012.

Kulmala, M., Lehtinen, K. E. J., and Laaksonen, A.: Cluster activation theory as an explanation of the linear dependence between formation rate of $3 \mathrm{~nm}$ particles and sulphuric acid concentration, Atmos. Chem. Phys., 6, 787-793, doi:10.5194/acp-6-787-2006, 2006.

Kulmala, M., Asmi, A., Lappalainen, H. K., Baltensperger, U., Brenguier, J.-L., Facchini, M. C., Hansson, H.-C., Hov, Ø., O'Dowd, C. D., Pöschl, U., Wiedensohler, A., Boers, R., Boucher, O., de Leeuw, G., Denier van der Gon, H. A. C., Feichter, J., Krejci, R., Laj, P., Lihavainen, H., Lohmann, U., McFiggans, G., Mentel, T., Pilinis, C., Riipinen, I., Schulz, M., Stohl, A., Swietlicki, E., Vignati, E., Alves, C., Amann, M., Ammann, M., Arabas, S., Artaxo, P., Baars, H., Beddows, D. C. S., Bergström, R., Beukes, J. P., Bilde, M., Burkhart, J. F., Canonaco, F., Clegg, S. L., Coe, H., Crumeyrolle, S., D’Anna, B., Decesari, S., Gilardoni, S., Fischer, M., Fjaeraa, A. M., Fountoukis, C., George, C., Gomes, L., Halloran, P., Hamburger, T., Harrison, R. M., Herrmann, H., Hoffmann, T., Hoose, C., Hu, M., Hyvärinen, A., Hõrrak, U., Iinuma, Y., Iversen, T., Josipovic, M., Kanakidou, M., Kiendler-Scharr, A., Kirkevåg, A., Kiss, G., Klimont, Z., Kolmonen, P., Komppula, M., Kristjánsson, J.-E., Laakso, L., Laaksonen, A., Labonnote, L., Lanz, V. A., Lehtinen, K. E. J., Rizzo, L. V., Makkonen, R., Manninen, H. E., McMeeking, G., Merikanto, J., Minikin, A., Mirme, S., Morgan, W. T., Nemitz, E., O’Donnell, D., Panwar, T. S., Pawlowska, H., Petzold, A., Pienaar, J. J., Pio, C., Plass-Duelmer, C., Prévôt, A. S. H., Pryor, S., Reddington, C. L., Roberts, G., Rosenfeld, D., Schwarz, J., Seland, Ø., Sellegri, K., Shen, X. J., Shiraiwa, M., Siebert, H., Sierau, B., Simpson, D., Sun, J. Y., Topping, D., Tunved, P., Vaattovaara, P., Vakkari, V., Veefkind, J. P., Visschedijk, A., Vuollekoski, H., Vuolo, R., Wehner, B., Wildt, J., Woodward, S., Worsnop, D. R., van Zadelhoff, G.-J., Zardini, A. A., Zhang, K., van Zyl, P. G., Kerminen, V.-M., S Carslaw, K., and Pandis, S. N.: General overview: European Integrated project on Aerosol Cloud Climate and Air Quality interactions (EUCAARI) - integrating aerosol research from nano to global scales, Atmos. Chem. Phys., 11, 13061-13143, doi:10.5194/acp11-13061-2011, 2011.

Kulmala, M., Kontkanen, J., Junninen, H., Lehtipalo, K., Manninen, H. E., Nieminen, T., Petäjä, T., Sipilä, M., Schobesberger, S., Rantala, P., Franchin, A., Jokinen, T., Järvinen, E., Äijälä, M., Kangasluoma, J., Hakala, J., Aalto, P. P., Paasonen, P., Mikkilä, J., Vanhanen, J., Aalto, J., Hakola, H., Makkonen, U., Ruuskanen, T. M., Mauldin III, R. L., Duplissy, J., Vehkamäki, H., Bäck, J., Kortelainen, A., Riipinen, I., Kurtén, T., Johnston, M. V., Smith, J. N., Ehn, M., Mentel, T. F., Lehtinen, K. E. J., Laaksonen, A., Kerminen, V.-M., and Worsnop, D. R.: Direct observations of atmospheric nucleation, Science, 339, 943-946, 2013.

Kulmala, M., Petäjä, T., Ehn, M., Thornton, J., Sipilä, M., Worsnop, D. R., and Kerminen, V.-M.: Chemistry of atmospheric nucleation: On the recent advances on precursor characterization and atmospheric cluster composition in connection with atmospheric new particle formation, Annu. Rev. Phys. Chem., 65, 21-37, 2014.

Kumar, P., Ketzel, M., Vardoulakis, S., Pirjola, L., and Britter, R.: Dynamics and dispersion modelling of nanoparticles from road traffic in the urban atmospheric environment - A review, J. Aerosol Sci., 42, 580-603, 2011.

Kumar, P., Pirjola, L., Ketzel, M., and Harrison, R. M.: Nanoparticle emissions from 11 non-vehicle exhaust sources: A review, Atmos. Environ., 67, 252-277, 2013. 
Kumar, P., Morawska, L., Birmili, W., Paasonen, P., Hu, M., Kulmala, M., Harrison, R. M., Norford, L., and Britter, R.: Ultrafine particles in cities, Environ. Int., 66, 1-10, 2014.

Lee, D. S., Pitari, G., Grewe, V., Gierens, K., Penne, J. E., Petzold, A., Prather, M. J., Schumann, U., Bais, A., Berntsen, T., Iachetti, D., Lim, L. L., and Sausen, R.: Transport impacts on atmosphere and climate: Aviation, Atmos. Environ., 44, 4678-4734, 2010.

Loane, C., Pilinis, C., Lekkas, T. D., and Politis, M.: Ambient particulate matter and its potential neurological consequences, Rev. Neurosciences, 24, 323-335, 2013.

Malkki, M., Niemi, J., Lounasheimo, J., Myllynen, M., Julkunen, A., and Loukkola, K.: Air quality in the Helsinki Metropolitan Area in 2009, Helsinki Region Environmental Services Authority (HSY) publications 2/2010, Edita Prima Oy, Helsinki, 124 pp., 2010.

Maricq, M. M.: Chemical characterization of particulate emissions from diesel engines: A review, J. Aerosol Sci., 38, 1079-1118, 2007.

McMurry, P.: A review of atmospheric aerosol measurements, Atmos. Environ., 34, 1959-1999, 2000.

Morawska, L., Bofinger, N. D., Kocis, L., and Nwankwoala, A.: Submicrometer and super micrometer particles from diesel vehicle emissions, Environ. Sci. Technol., 32, 2033-2042, 1998.

Morawska, L., Ristovski, Z., Jayaratne, E. R., Keogh, D. U., and Ling, X.: Ambient nano and ultrafine particles from motor vehicle emissions: Characteristics, ambient processing and implications on human exposure, Atmos. Environ., 42, 8113-8138, 2008.

Moussiopoulos, N., Flassak, Th., Berlowitz, D., and Sahm, P.: Simulations of the wind field in Athens with the nonhydrostatic mesoscale model MEMO, Environ. Softw., 8, 29-42, 1993.

Moussiopoulos, N., Sahm, P., and Kessler, Ch.: Numerical simulation of photochemical smog formation in Athens, Greece - a case study, Atmos. Environ., 29, 3619-3632, 1995.

Moussiopoulos, N., Helmis, C. G., Flocas, H. A., Louka, P., Assimakopoulos, V. D., Naneris, C., and Sahm, P.: A modelling method for estimating transboundary air pollution in southeastern Europe, Environ. Model. Softw., 19, 549-558, 2004.

Moussiopoulos, N., Douros, I., Tsegas, G., Kleanthous, S., and Chourdakis, E.: An Air Quality Management System for Policy Support in Cyprus, Adv. Meteorol., 2012, 959280, doi:10.1155/2012/959280, 2012.

Nel, A., Xia, T., Madler, L., and Li, N.: Toxic potential of materials at the nanolevel, Science, 311, 622-627, 2006.

Obaidullah, M., Verma, V. K., and Ruyck, V. K.: A Review on Particle Emissions from Small Scale Biomass Combustion, Int. J. Renew. Ener. Res., 2, 147-159, 2012.

Oberdörster, G., Sharp, Z., Atudorei, V., Elder, A., Gelein, R., Kreyling, W., and Cox, C.: Translocation of inhaled ultrafine particles to the brain, Inhal. Toxicol., 16, 1-9, 2004.

Olivares, G., Johansson, C., Ström, J., and Hansson, H. C.: The role of ambient temperature forparticle number concentrations in a street canyon, Atmos. Environ., 41, 2145-2155, doi:10.1016/j.atmosenv.2006.10.068, 2007.

Paasonen, P., Asmi, A., Petäjä, T., Kajos, M. K., Äijälä, M., Junninen, H., Holst, T., Abbatt, J. P. D., Arneth, A., Birmili, W., Denier van den Gon, H., Hamed, A., Hoffer, A., Laaksonen, A., Laakso, L., Leaitch, R., Plass-Dülmer, C., Pryor, S. C., Räisänen, P., Swietlicki, E., Wiedensohler, A., Worsnop, D. R., Kerminen, V.-M., and Kulmala, M.: Warming-induced increase in aerosol number concentration likely to moderate climate change, Nat. Geosci., 6 , 438-442, doi:10.1038/NGEO1800, 2012.

Petzold, A., Weingartner, E., Hasselbach, J., Lauer, P., Kurok, C., and Fleischer, F.: Physical properties, chemical composition, and cloud forming potential of particulate emissions from a marine diesel engine at various load conditions, Environ. Sci. Technol., 44, 3800-3805, doi:10.1021/es903681z, 2010.

Pohjola, M. A., Pirjola, L., Kukkonen, J., and Kulmala, M.: Modelling of the influence of aerosol processes for the dispersion of vehicular exhaust plumes in street environment, Atmos. Environ., 37, 339-351, 2003.

Pohjola, M. A., Pirjola, L., Karppinen, A., Härkönen, J., Korhonen, H., Hussein, T., Ketzel, M., and Kukkonen, J.: Evaluation and modelling of the size fractionated aerosol particle number concentration measurements nearby a major road in Helsinki - Part I: Modelling results within the LIPIKA project, Atmos. Chem. Phys., 7, 4065-4080, doi:10.5194/acp-7-4065-2007, 2007.

Riipinen, I., Pierce, J. R., Yli-Juuti, T., Nieminen, T., Häkkinen, S., Ehn, M., Junninen, H., Lehtipalo, K., Petäjä, T., Slowik, J., Chang, R., Shantz, N. C., Abbatt, J., Leaitch, W. R., Kerminen, V.-M., Worsnop, D. R., Pandis, S. N., Donahue, N. M., and Kulmala, M.: Organic condensation: a vital link connecting aerosol formation to cloud condensation nuclei $(\mathrm{CCN})$ concentrations, Atmos. Chem. Phys., 11, 3865-3878, doi:10.5194/acp-11-38652011, 2011.

Ristovski, Z., Jayaratne, E. R., Lim, M., Ayoko, G. A., and Morawska, L.: Influence of diesel fuel sulphur on the nanoparticle emissions from city buses, Environ. Sci. Technol., 40, 13141320, 2006.

Rönkkö, T., Virtanen, A., Kannosto, J., Keskinen, J., Lappi, M., and Pirjola, L.: Characteristics of nucleation mode particles in exhaust of Euro IV heavy duty diesel vehicle, Environ. Sci. Technol., 41, 6384-6389, 2007.

Samaras, Z., Moussiopoulos, N., Douros, I., Samaras, C., Vouitsis, E., Tsegas, G., Chourdakis, E., Mitsakis, E., Salanova-Grau, J. M., Aifadopoulou, G., Stamos, I., Gotti, A., and Sarigiannis, D. A.: Transport emissions and their impact on air quality in Athens: A case study in the framework of TRANSPHORM project, Proceedings of the 19th International Transport and Air Pollution Conference 2012 (TAP), 26-27 November 2012, Thessaloniki, Greece,, 2012.

Schaap, M., Timmermans, R. M. A., Roemer, M., Boersen, G. A. C., Builtjes, P. J. H., Sauter, F. J., Velders, G. J. M., and Beck, J. P.: The LOTOS-EUROS model: description, validation and latest developments, Int. J. Environ. Pollut., 32, 270-290, 2008.

Sfetsos, A., Vlachogiannis, D., Gounaris, N., and Stubos, A. K.: On the identification of representative samples from large data sets, with application to synoptic climatology, Theor. Appl. Climatol., 82, 177-182, 2005.

Shahgedanova, M., Burt, T. P., and Davies, T. D.: Synoptic Climatology of Air Pollution in Moscow, Theor. Appl. Climatol., 61, 85-102, 1998.

Shi, J. P., Evans, D. E., Khan, A. A., and Harrison, R. M.: Sources and concentration of nanoparticles $(<10 \mathrm{~nm}$ diameter $)$ in the urban atmosphere, Atmos. Environ., 45, 1193-1202, 2001.

Singh, V., Sokhi, R. S., and Kukkonen, J.: $\mathrm{PM}_{2.5}$ concentrations in London for 2008 - A modelling analysis of con- 
tributions from road traffic, J. Air Waste Ma., 64, 509-518, doi:10.1080/10962247.2013.848244, 2013.

Skamarock, W. C., Klemp, J. B., Dudhia, J., Gill, D. O., Barker, D. M., Wang, W., and Powers, J. G.: A description of the Advanced Research WRF Version 2, NCAR Tech Notes-468+STR, 2005.

Slordal, L. H., McInness, H., and Krognes, T.: The Air Quality Information System AirQUIS, Environ. Sci. Eng., 1, 40-47, 2008.

Smith, K. R., Jerrett, M., Ross Anderson, H., Burnett, R. T., Stone, V., Derwent, R., Atkinson, R. W., Cohen, A., Shonkoff, S. B., Krewski, D., Pope III, C. A., Thun, M. J., and Thurston, G.: Public health benefits of strategies to reduce greenhouse-gas emissions: health implications of short-lived greenhouse pollutants, Lancet, Series Health and Climate Change, 5, 1-13, doi:10.1016/S0140-6736(09)61716-5, 2009.

Snijder, A., Wester, B., and van den Elshout, S.: Improved spatially resolved emissions in the Rotterdam Rijnmond region, in: Matthias and Aulinger, CNSS report on activity 1 in workpackage 5: Monitoring and simulation of pollutant generation and spread, Institute of Coastal Research, Helmholtz-Zentrum Geesthacht, 2012, available at: http: //cnss.no/wp-content/uploads/2012/12/monitoring-rap-web.pdf (last access: 1 February 2016), 2012.

Soares, J., Kousa, A., Kukkonen, J., Matilainen, L., Kangas, L., Kauhaniemi, M., Riikonen, K., Jalkanen, J.-P., Rasila, T., Hänninen, O., Koskentalo, T., Aarnio, M., Hendriks, C., and Karppinen, A.: Refinement of a model for evaluating the population exposure in an urban area, Geosci. Model Dev., 7, 1855-1872, doi:10.5194/gmd-7-1855-2014, 2014.

Sokhi, R. S., Mao, H., Srimath, S. T. G., Fan, S., Kitwiroon, N., Luhana, L., Kukkonen, J., Haakana, M., van den Hout, K. D., Boulter, P., McCrae, I. S., Larssen, S., Gjerstad, K. I., San Jose, R., Bartzis, J., Neofytou, P., van den Breemer, P., Neville, S., Kousa, A., Cortes, B. M., Karppinen, A., and Myrtveit, I.: An Integrated Multi-model Approach for Air Quality Assessment: Development and Evaluation of the OSCAR Air Quality Assessment System, Environ. Model. Softw., 23, 268-281, doi:10.1016/j.envsoft.2007.03.006, 2008.

Solazzo, E., Bianconi, R., Vautard, R., Appel, K. W., Moran, M. D., Hogrefe, C., Bessagnet, B., Brandt, J., Christensen, J. H., and Chemel, C.: Model evaluation and ensemble modelling of surface-level ozone in Europe and North America in the context of AQMEII, Atmos. Environ., 53, 60-74, 2012a.

Solazzo, E., Bianconi, R., Pirovano, G., Matthias, V., Vautard, R., Moran, M. D., Wyat Appel, K., Bessagnet, B., Brandt, J., and Christensen, J. H.: Operational model evaluation for particulate matter in Europe and North America in the context of AQMEII, Atmos. Environ., 53, 75-92, 2012b.

Stern, R., Builtjes, P., Schaap, M., Timmermans, R., Vautard, R., Hodzic, A., Memmesheimer, M., Feldmann, H., Renner, E., Wolke, R., and Kerschbaumer, A.: A model inter-comparison study focussing on episodes with elevated $\mathrm{PM}_{10}$ concentrations, Atmos. Environ., 42, 4567-4588, 2008.

Stolzel, M., Breitner, S., Cyrys, J., Pitz, M., Wölke, G., Kreyling, W., Heinrich, J., Wichmann, H.-E., and Peters, A.: Daily mortality and particulate matter in different size classes in Erfurt, Germany, J. Expos. Sci. Environ. Epidemiol., 17, 458-467, doi:10.1038/sj.jes.7500538, 2007.
UNECE: Light Duty Diesel Vehicle Particle Number Round Robin, Informal Document GRPE-059-05, Transmitted by experts from OICA, 2010.

Vardoulakis, S., Fisher, B. E. A., Pericleous, K., and GonzalesFlesca, N.: Modelling air quality in street canyons: a review, Atmos. Environ., 37, 155-182, 2003.

Vignati, E., Wilson, J., and Stier, P.: M7: an efficient sizeresolved aerosol microphysics module for large-scale aerosol transport models, J. Geophys. Res., 109, D22202, doi:10.1029/2003JD004485, 2004.

von Bismarck-Osten, C., Birmili, W., Ketzel, M., Massling, A., Petäjä, T., and Weber, S.: Characterization of parameters influencing the spatio-temporal variability of urban particle number size distributions in four European cities, Atmos. Environ., 77, 415-429, 2013.

Von Klot, S., Peters, A., Aalto, P., Bellander, T., Berglind, N., D’Ippoliti, D., Elosua, R., Hörmann, A., Kulmala, M., Lanki, T., Löwel, H., Pekkanen, J., Picciotto, S., Sunyer, J., Forastriere, F., and the HEAPSS study group: Ambient air pollution is associated with increased risk of hospital cardiac readmission of myocardial infarction survivors in five European cities, Circulation, 112, 3073-3079, 2005.

Vouitsis, I., Ntziachristos, L., Samaras, Ch., and Samaras, Z.: Quantification of road transport particulate matter using detailed technology emission factors. TRA2014 Transport Research Arena 2014, Transport Solutions: from Research to Deployment - Innovate Mobility, Mobilise Innovation, 14-17 April 2014, Paris La Défense, France, Transport Research Arena (TRA) 2014 Proceedings, Accession Number: 01528196, 10 pp., available at: http://trid.trb.org/view/2014/C/1327771 (last access: 1 February 2016), 2014.

Wehner, B., Birmili, W., Gnauk, T., and Wiedensohler, A.: Particle number size distributions in a street canyon and their transformation into the urban-air background: measurements and a simple model study, Atmos. Environ., 36, 2215-2223, 2002.

Wesseling, J. P. and Visser, G. Th.: An inter-comparison of the TNO Traffic Model, field data and wind tunnel measurements, TNO, Utrecht, the Netherlands, Report 2003/207, 2003.

Westerdahl, D., Fruin, S. A., Fine, P. L., and Sioutas, C.: The Los Angeles International Airport as a source of ultrafine particles and other pollutants to nearby communities, Atmos. Environ., 42, 3143-3155, 2008.

Wiedensohler, A., Birmili, W., Nowak, A., Sonntag, A., Weinhold, K., Merkel, M., Wehner, B., Tuch, T., Pfeifer, S., Fiebig, M., Fjäraa, A. M., Asmi, E., Sellegri, K., Depuy, R., Venzac, H., Villani, P., Laj, P., Aalto, P., Ogren, J. A., Swietlicki, E., Williams, P., Roldin, P., Quincey, P., Hüglin, C., Fierz-Schmidhauser, R., Gysel, M., Weingartner, E., Riccobono, F., Santos, S., Grüning, C., Faloon, K., Beddows, D., Harrison, R., Monahan, C., Jennings, S. G., O’Dowd, C. D., Marinoni, A., Horn, H.-G., Keck, L., Jiang, J., Scheckman, J., McMurry, P. H., Deng, Z., Zhao, C. S., Moerman, M., Henzing, B., de Leeuw, G., Löschau, G., and Bastian, S.: Mobility particle size spectrometers: harmonization of technical standards and data structure to facilitate high quality long-term observations of atmospheric particle number size distributions, Atmos. Meas. Tech., 5, 657-685, doi:10.5194/amt5-657-2012, 2012.

Zhang, K. M. and Wexler, A. S.: Evolution of particle number distribution near roadways - Part I: Analysis of aerosol dynamics 
and its implications for engine emission measurement, Atmos. Environ., 38, 6643-6653, 2004.

Zhang, K. M., Wexler, A. S., Zhu, Y. F., Hinds, W. C., and Sioutas, C.: Evolution of particle number distribution near roadways. Part II: The "road-to-ambient" process, Atmos. Environ., 38, 66556665, 2004.
Zhu, Y., Fanning, E., Yu, R. C., Zhang, Q., and Froines, J. R.: Aircraft emissions and local air quality impacts from takeoff activities at a large International Airport, Atmos. Environ., 45, 65266533, 2011. 